Geise Bernadelli Guerra Enders

Não falei - O trabalho de memória na narrativa de um sobrevivente

Brasília

março de 2015 
Geise Bernadelli Guerra Enders

\title{
Não falei - O trabalho de memória na narrativa de um
}

\author{
sobrevivente
}

Dissertação apresentada como requisito parcial para obtenção do grau de Mestre em Literatura pelo Programa de PósGraduação em Literatura do Departamento de Teoria Literária e Literaturas do Instituto de Letras da Universidade de Brasília.

\author{
Universidade de Brasília \\ Instituto de Letras \\ Departamento de Teoria Literária e Literaturas \\ Programa de Pós-Graduação em Literatura
}

Orientadora: Sara Almarza

Brasília

março de 2015 
(ficha catalográfica) 
Geise Bernadelli Guerra Enders

\section{Não falei - $\mathrm{O}$ trabalho de memória na narrativa de um sobrevivente}

Dissertação defendida e aprovada em 24 de março de 2015 pela banca examinadora:

Profa. Dra. Sara Almarza

(Orientadora)

Prof. Dr. Hermenegildo José de Menezes Bastos

(Membro interno)

Prof. Dr. Daniel Barbosa Andrade de Faria

(Membro externo) 
Para Pedro e Helena, forças motrizes do meu crescimento. 


\section{Agradecimentos}

À providência divina, que renova minha fé nos momentos felizes e me ampara nos momentos difíceis.

Ao Bernhard, amor de tantos tempos, aliado valoroso na criação de nossos filhos, e cuja ajuda inestimável propiciou a finalização deste trabalho a contento.

À minha querida mãe, Wilma, por sempre ter acreditado no caráter transformador da educação.

Aos meus familiares, que me apoiaram, que compreenderam e relevaram minhas constantes ausências.

Aos meus amigos, pelo incentivo. Especialmente à Marília, pela amizade e pelas tertúlias regadas a vinho e filosofia.

À minha orientadora, Sara, que amorosamente acolheu minhas demandas e pacientemente me guiou pelos sinuosos caminhos da pesquisa acadêmica.

Aos colegas do grupo de pesquisa sobre a memória, pela incalculável riqueza de discussões. Especialmente à Sheila, Yara, Pollyana, Morganna, Jane e Zuleica, pelas preciosas contribuições à clareza deste trabalho.

Aos professores do PosLit, que enriqueceram minha fortuna crítica e acrescentaram sobremaneira à minha maturação intelectual. Também ao professor Luciano Ponzio, por compartilhar seus conhecimentos sobre semiótica e Chagall. 
Era ainda jovem demais para saber que a memória do coração elimina as más lembranças e enaltece as boas e que graças a esse artifício conseguimos suportar o passado.

- Gabriel García Márquez, O amor nos tempos do cólera. 


\section{Resumo}

A narrativa de um velho educador, sobrevivente da ditadura militar brasileira, é o objeto de pesquisa deste trabalho. Na obra Não falei, de Beatriz Bracher, o protagonista, Gustavo, nomeia suas recordações de lembranças quebradas e lembrança certa, e as apresenta na narrativa - ora via simples relatos, ora via construção de imagens - tal como the vão aflorando. Examino essas lembranças à luz da filosofia fenomenológica de Paul Ricoeur, buscando compreender do que o narrador se lembra e de que maneira essas lembranças se configuram em sua memória; estabelecendo relações entre o que sua narrativa revela com o modo como conduziu sua vida após os eventos decorrentes de sua prisão. As análises partem de indícios e de rastros deixados pelos vazios, silêncios e ausências identificados na peculiar construção textual e que fornecem elementos essenciais para a compreensão da complexidade da história do personagem. As metalinguagens e referências literárias presentes no romance mostram-se precisas e são detidamente analisadas, sobretudo pela importância que têm para o preenchimento de sentidos pelo leitor. Averigua-se, por fim, que as reflexões suscitadas pelo revisitar do passado permitem ao personagem ressignificar sua história e aos leitores recuperar a realidade educacional e política brasileira do período ditatorial e suas consequências para a atualidade.

Palavras-chaves: Vazios. Memória. Sobrevivente. Ditadura. Educação. Bracher. Ricoeur. 


\section{Abstract}

The narrative of an old educator, survivor of the military dictatorship in Brazil, is the research object of the present work. In the book by Beatriz Bracher, entitled Não falei, the protagonist, Gustavo, names his memories as broken remembrances and certain remembrance, and presents the narrative - sometimes via simple reports, sometimes through the construction of images - as they arise. I examine these memories in the light of the phenomenological philosophy of Paul Ricoeur, trying to understand what the narrator remembers and how these remembrances are configured in his memory; establishing a relationship between what his narrative reveals and the manner his conducted his life after the events stemming from his arrest. The analyses begin with clues and traces left by the empties, silences and absences identified in the peculiar textual construction, which provides essential elements for understanding the complexity of the history of the character. Metalanguages and literary references in the novel are accurate and are analysed in detail, particularly by the importance that they have in filling the meanings by the reader. Finally, it is ascertained that the reflections raised in revisiting the past allowed the character to resignify its history and the readers to retrieve the Brazilian education and politics reality of the dictatorial period and its consequences for the present.

Keywords: Empties. Memory. Survivor. Dictatorship. Education. Bracher. Ricoeur. 


\section{Sumário}

Introdução ............................ 10

$1 \quad$ VAZIOS, SILÊNCIOS E AUSÊNCIAS $\ldots \ldots \ldots \ldots$

2 LEMBRANÇA QUEBRADA E LEMBRANÇA CERTA . . . . . . . 30

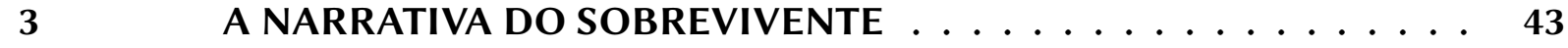

Conclusão $\ldots \ldots \ldots \ldots \ldots \ldots \ldots \ldots$

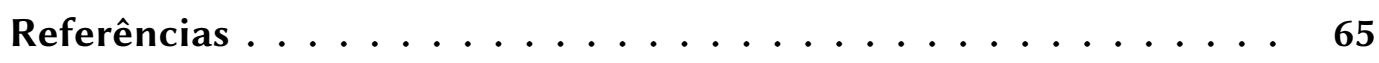




\section{Introdução}

Se fosse possível um pensamento sem palavras ou imagens, inteiro sem tempo ou espaço, mas por mim criado, uma revelação do que em mim e de mim se esconde [...] se coisa assim fosse possível existir, eu gostaria de contar uma história.

- Beatriz Bracher, Não Falei.

Título do romance de Beatriz Bracher que é o objeto desta pesquisa, Não falei é uma expressão veemente e que adianta ao leitor o teor da narrativa: algo não foi dito. As questões que me ocorreram quando observei pela primeira vez a capa dessa obra foram justamente essas: o que não foi dito? Quem não disse? As palavras iniciais do romance estão reproduzidas na presente epígrafe e denotam o raciocínio complexo de um narrador que não quer contar sua história. Professor desde muito jovem, casado com Eliana, irmã de Armando, seu amigo de infância, a situação exposta pelo protagonista é bem peculiar; Gustavo é um velho homem solitário que vive na antiga casa de sua família, aos sessenta e quatro anos está se aposentando como professor universitário e decide continuar a trabalhar, mas num novo ambiente, vendendo a casa e mudando-se da metrópole para uma pequena cidade interiorana. As despedidas e homenagens na universidade o enfadam devido às menções à sua pessoa no tempo passado, ele afirma que esse enterro em vida não lhe convém, pois busca justamente renovar-se com o desafio que deseja enfrentar.

Neste momento em que se encontra tem de lidar com a venda e desocupação da casa, o que lhe obriga a revirar objetos e papéis dos entes que partilharam com ele muitas situações naquela morada, aflorando-lhe assim diversas lembranças. A visita do irmão por conta da venda e os manuscritos de seu mais novo romance também mexem com sua memória. Além das despedidas em vida no trabalho, há ainda uma entrevista que deve conceder à jovem escritora Cecília, que está construindo uma história cujo personagem principal tem uma trajetória semelhante à de Gustavo.

Tantas mudanças em sua rotina e em sua vida trazem à tona elementos de seu passado, rememora o trabalho como diretor nas escolas, os episódios marcantes 
por que passou, os relatórios e cartas que escreveu à secretaria de educação sobre os atuais rumos do ensino público e os vários cursos de recapacitação de professores que ministrou. Sua opção fora sempre por resistir à ditadura através do trabalho em sala de aula, incitando em seus alunos uma educação questionadora.

Naturalmente, é também acometido por lembranças de sua prisão pelo regime militar e das torturas a que fora submetido, bem como das consequências desse evento ao longo de sua vida. Gustavo fora preso pelos militares a fim de delatar informações que pudessem levá-los ao amigo. Diferentemente do cunhado, Armando militava contra o golpe na linha de frente dos movimentos e, secretamente, nas organizações armadas. Para evitar outra prisão, colegas do grupo enviaram Eliana a Paris, deixando no Brasil a filha do casal, Lígia, ainda bebê. O professor pouco sabia das ações do cunhado, tampouco de seu alijamento secreto às organizações, menos por isso e muito mais pela irmandade sincera devotada ao amigo, ele nada falou. Suportou terríveis torturas, mas não falou. Entretanto, três dias após sua libertação, Armando fora pego, torturado e morto pelos militares. Além das dores e desfiguração de seu corpo, Gustavo tinha de lidar com a culpa da delação a ele veladamente atribuída e com o sofrimento pela perda do amigo. Logo em seguida, Eliana morrera de pneumonia longe dele e, para completar a tragédia, a sogra, desesperada pela perda dos dois filhos, suicida-se depois de ter atribuído a ele sua profunda decepção.

Sua memória quebrada, como o próprio narrador descreve, e as lembranças que as situações citadas evocaram, conduzem Gustavo a refletir profundamente sobre sua vida e os rumos que ela tomou após os traumas desencadeados por sua prisão. À medida que a narrativa se desenrola e que as lembranças vão surgindo, embaralhadas, podemos associá-las e ter mais clareza sobre a personalidade desse homem que, de um simples velho que está se aposentando e recordando seu passado, revela-se de uma grande complexidade, apresentando-nos profundas reflexões sobre a natureza humana a partir de sua experiência de vida: "Para que educar? Criar homens livres, revolucionários, críticos, úteis, cidadãos, cada década com seu objetivo, e agora? Não há saída fora da complexidade." (BRACHER, 2004, p. 46). 
Contada assim, de maneira pragmaticamente resumida, a história desse personagem dissipa a complexidade do enredo que, magistralmente, nos é apresentada no romance. De uma riqueza na estrutura da construção e no trabalho da linguagem, Não falei suscita-nos profundas reflexões e questionamentos acerca das relações humanas, dos afetos que nos são caros, dos traumas de cada um e suas reverberações por toda a vida; bem como sobre o sistema educacional brasileiro e sobre o último período ditatorial por que passamos. Sobretudo, esse romance é um trabalho de memória em que, no esforço narrativo de Gustavo, algumas lembranças são por ele buscadas e outras lhe surgem a partir de elementos que lhe são externos. Nessa tessitura da intriga o velho professor consegue ressignificar seu passado, reconciliando-se consigo mesmo, vivenciando e encerrando seu luto e, ao final desse percurso e por causa dele, concretiza uma memória feliz ${ }^{1}$, que coroa a narrativa e proporciona-lhe seu reconhecimento.

Interessa-me analisar detidamente três objetos de Não falei, que exploro em capítulos diferentes, mas que são complementares entre si: os vazios, a memória e a narrativa do sobrevivente.

No primeiro capítulo debruço-me sobre os vazios da trama, que subdivido em vazios, silêncios e ausências, por similaridades de forma ou de apresentação das ocorrências. Essas lacunas podem ser notadas pela própria estrutura de certos trechos, nos quais falta, de fato, a enunciação do signo, e que nomeei vazios. Há eventos, os quais designo silêncios, em que espécies de supressões deixam inexplicáveis comportamentos e condutas dos personagens. Por fim, identifico os que não são expressos na linguagem, mas que sugerem uma imensa lacuna psíquica sobre Gustavo, referindome a eles pelo termo ausências.

O segundo capítulo é dedicado ao estudo detido dos desdobramentos da memória do narrador, nomeados pelo próprio de lembranças quebradas e lembrança certa. A situação presente de Gustavo e suas expectativas de futuro conduzem-no para a revisitação de seu passado. Por meio das lembranças que lhe surgem embaralhadas, quebradas, ele pode refletir sobre os acontecimentos pregressos e suas consequências, bem como pode visualizar o que, de fato, era responsabilidade sua e o

\footnotetext{
1 Termo cunhado por Ricoeur (2007, p. 502), contextualizado no segundo capítulo deste trabalho.
} 
que deveria ser imputado ao outro ou às circunstâncias, resultando numa lembrança certa que propiciou um fortuito desfecho.

A narrativa do sobrevivente é analisada no terceiro capítulo e refere-se tanto aos recursos textuais empregados para propiciar ao leitor a compreensão dos sentimentos de Gustavo, quanto à citação de três autores literários cujas trajetórias assemelham-se, em certa medida, à história do personagem. A convocação de João Cabral de Melo Neto, de Primo Levi e de Graciliano Ramos, mostra-se propícia pelos elementos que a trajetória dos três tem em comum com a de Gustavo.

Os estudos fenomenológicos de Paul Ricoeur fornecem as diretrizes para as análises empenhadas nesta pesquisa, bem como os dos pensadores convocados por ele, de diversas partes e contextos históricos, como Henri Bergson e Santo Agostinho. A abordagem investigativa que adoto segue os rastros e os sinais deixados pela narrativa, herança das leituras de Carlo Guinzburg, que tanto acrescentaram à maturação deste trabalho.

Inicio o trabalho certa de oferecer uma leitura minuciosa sobre a trajetória de Gustavo, de suas vitórias e dores. Na esteira de Santo Agostinho, sinto que, vencendo a vida, o tempo esculpe suas marcas e a visita aos palácios da memória se faz inevitável para a compreensão e aquiescência com os caminhos que, grande parte das vezes, não escolhemos trilhar. Não falei é uma expressão desta necessidade humana de olhar para seu próprio passado a fim se reconhecer nele para seguir vivendo. Pelas trilhas do romance, justifico a relevância desta análise utilizando a reflexão de Gustavo sobre a literatura: “Quem sabe apenas aí a tal humanidade encontre seu rosto e possamos falar do que realmente importa." (BRACHER, 2004, p. 56). 


\section{Vazios, silêncios e ausências}

Cintilante é a água em uma bacia; escura é a água no oceano. A pequena verdade tem palavras que são claras; a grande verdade tem grande silêncio. - Rabindranath Tagore, Pássaros errantes, CLXXVI.

A princípio, quando se analisa uma narrativa literária, detemo-nos no que aquele encadeamento de palavras nos diz, no que podemos extrair dos signos postos no papel que expressam, por meio do código linguístico, uma história. No entanto, após uma leitura mais detida, percebemos nos detalhes dessa linguagem nuances do enredo que são caprichosamente envoltas em palavras escolhidas para não deixarem tão evidentes alguns aspectos da trama, trata-se do que podemos abstrair das entrelinhas com uma leitura mais minuciosa.

Ocorre que, para além desse velamento parcial da história, deparamo-nos por diversas vezes com vazios, grandes ou pequenos, na própria linguagem configurados pela falta do signo ou na tessitura da intriga configurados pela ausência de elementos. Esses vazios, justamente por assim apresentar-se, devem ser preenchidos para que o todo faça sentido, e quem os preenche são os leitores, cada um a partir de suas experiências pessoais.

Segundo a teoria de Iser (1979), essa relação texto-leitor é uma forma de interação ${ }^{1}$, pois, apesar de não estabelecer uma situação face a face em que as partes alternam o controle da contingência, o texto é permeado de vazios que só podem ser preenchidos por quem o lê, de acordo com suas experiências; no entanto, o leitor não poderá retirar do texto alguma certeza explícita de que sua compreensão é a correta.

Essa interação apresenta, portanto, elementos diádicos em certa medida, mas é assimétrica posto que seu sucesso ou fracasso depende do horizonte de referência de cada um. O fracasso impera quando quem lê preenche os vazios do texto apenas

$1 \quad$ Wolfgang Iser desenvolve seus pressupostos sobre a interação do texto com o leitor a partir da assimetria fundamental que existe entre as duas partes. Segundo ele, os graus de indeterminação dessa assimetria, da contingência e do nonada são as diferentes formas de um vazio constitutivo pelo qual se estabelecem as relações de interação. 
com as próprias projeções, e só obtém sucesso quando a leitura provoca tamanha multiplicidade de representações do leitor que este se vê obrigado a abandonar suas próprias representações possíveis para se abrir ao horizonte de referência que a obra impõe, corrigindo assim suas projeções. A assimetria entre texto e leitor só cessa com esse processo, por isso não pode ser determinada de antemão, e é esta própria indeterminação que permite as múltiplas possibilidades de comunicação.

Em Não falei há inúmeros vazios. Há os estruturais, de faltas de signos linguísticos para completar algumas orações; há os que suprimem elementos do relato que deixam sem explicação comportamentos e condutas dos personagens e, por fim, há os que estão expressos na linguagem, mas que sugerem uma lacuna psíquica inenarrável. Para diferenciar essas três formas de apresentação dos vazios nesse romance nomeei-as de vazios, silêncios e ausências, respectivamente.

\section{Vazios}

Há várias ocorrências de vazios por falta de signos linguísticos na obra e duas delas despertaram minha atenção pelo fato de a própria ausência das palavras denotar a complexidade do que estava sendo tratado ali.

A primeira surge após Gustavo narrar a história de suas intervenções pedagógicas com o garoto Benício, o relato de todas as ações do então diretor para resgatar a dignidade daquele aluno, tanto junto ao próprio garoto quanto junto aos seus pais e professores e todos os percalços dessa longa trajetória se encerram com uma constatação:

Acho que ele está bem, será bem aceito no time enquanto agarrar bem, será bem aceito pelos professores enquanto cumprir seus deveres, será bem aceito na vida enquanto. É goleiro de nossa seleção de handebol e fala em fazer faculdade. (BRACHER, 2004, p. 55).

Qual seria o verbo ideal para condicionar o será bem aceito na vida? Gustavo não coloca, apesar de ter relatado em detalhes todas as intervenções que fez e seus resultados durante o processo de resgate desse aluno, o narrador não determina o futuro desse sujeito simplesmente porque isso não pode ser determinado, mesmo após 
ter obtido sucesso naquela jornada. O leitor que se depara com essa ausência frustra sua projeção de que a vida daquele garoto havia mudado para sempre e que seu futuro de sucesso estaria garantido; é obrigado a abandonar as expectativas de final feliz que uma leitura casual busca e confrontar-se com uma reflexão sobre a realidade instável da vida humana, aceitando que nada é imutável, mesmo obedecendo-se a inúmeras condicionantes. Esse vazio representado pelo ponto final quando se esperaria ainda um verbo, uma ação condicionante para o sucesso, é a expressão de um pensamento sobre a vida e, ao assim apresentar-se, permite ao leitor recriar em seu próprio pensamento uma reflexão, partindo da identificação com suas experiências pessoais.

Recorro a Merleau-Ponty, que estudou e descreveu o caráter específico da linguagem:

\begin{abstract}
A falta de um signo pode ser ela mesmo um signo e a expressão não consiste em que haja um elemento da linguagem para se ajustar a cada elemento de sentido, mas sim na influência da linguagem sobre a linguagem, que, de súbito, muda na direção de seu sentido. [...] Se a linguagem renuncia a enunciar a própria coisa, irrevogavelmente a expressa. [...] A linguagem é significativa quando, em vez de copiar o pensamento, se permite dissolver-se e recriar-se pelo pensamento. (MERLEAU-PONTY, 1967 apud ISER, 1979, p. 91).
\end{abstract}

Assim, a falta do signo condicionante após o último "enquanto" é ela mesma um signo, pois serve primeiro para desestabilizar o leitor frustrando-o em suas projeções e, posteriormente, identifica para esse leitor que essa falta representa a própria incerteza da vida. É uma instabilidade apresentada por um vazio no texto que se dissolve pela identificação do leitor com suas próprias experiências, operando em seu pensamento uma recriação da questão de Benício para uma questão da existência humana.

Outra ocorrência de vazios por falta de signos linguísticos no romance é encontrada num dos trechos que Gustavo nomeia de "outro como eu - conversa recente" (BRACHER, 2004, p. 129, grifo do autor). Há várias inserções de outro como eu ao longo do livro e que são, acredito, falas de outras pessoas em diferentes momentos, que foram assimiladas e se tornaram diálogos dele consigo mesmo, ou confrontos de 
um Gustavo do passado que ficou tão distante de si que se tornou quase um estranho e, por isso, o nomeia de outro. No entanto, esse diálogo é sempre recente, ou seja, esse confronto com um eu passado dá-se no momento presente da narrativa, em que ele se vê obrigado a olhar para si e para o que já viveu para poder olhar para frente e recomeçar.

O trecho em questão é a síntese de várias vozes de colegas de trabalho da escola em que Gustavo era diretor à época de sua prisão e, ao mesmo tempo, é também a voz do próprio narrador que adotava aquele procedimento sempre que alguém da escola desaparecia. O relato é do momento em que deixam claro para os militares que a prisão do diretor era conhecida e, apesar de arriscarem serem presos também, foram à porta do DOI-CODI dizer que precisavam de algumas bobagens e assinaturas. Foram atendidos por um militar:

[...] e quem nos atendeu era assim um gordinho, suava, suava, suava e aí a gente começou a conversar com ele. Ele era de Santos, ele falou do Pelé, não sei o quê, e acabou resolvendo. Claro, não foi por isso que ele foi solto, mas. Eu fico pensando na loucura que foi isso, você vai na boca do. Meu Deus, meu Deus. (BRACHER, 2004, p. 129).

Mais uma vez a linguagem literária aqui se recusa a enunciar o signo, mas fazendo isso o expressa. Esse tipo de supressão é uma forma de negação, como afirma Wolfgang Iser, que contribui de diferentes maneiras para o processo de comunicação.

A supressão das palavras após o "mas" sugere que o fato de conversarem com o militar sobre o ídolo do futebol santista ajudou na libertação do diretor, o que pode denotar inúmeras coisas, tais como a representação do "jeitinho brasileiro", ou a instabilidade dos sujeitos a serviço do regime, ou uma crítica às falhas do sistema de inteligência dos militares por se permitirem ser enganados facilmente. Enfim, de acordo com as experiências de cada leitor esse vazio será preenchido por uma ou outra concepção, pois é ele quem coordena as perspectivas de representação do texto.

O segundo vazio deste trecho, "você vai na boca do.", mais que proposital para deixar que algo seja completado pela experiência do leitor, configura-se como um recurso da linguagem para evidenciar a estupefação pelo feito daquelas pessoas, reforçada na expressão final: "Meu Deus, meu Deus". A admiração ressaltada no texto 
é pela coragem que elas tiveram de ir à porta do DOI-CODI confrontar os militares pela libertação do diretor, arriscando serem presas também, mesmo sabendo de todas as atrocidades que eram cometidas ali dentro. Nesse caso, colocar a expressão popular "boca do inferno" seguida de uma exclamação, por exemplo, não seria suficiente para provocar tamanha estupefação no leitor quanto a ausência do termo e a sucessão de invocações a Deus.

Gustavo conhece o alcance do efeito de um texto quando esse é lapidado e uma reflexão sua conclui essa análise:

[...] a ausência do verbo apaga a pessoa e o tempo, deixa-os em suspenso, mas, curiosamente, mantém a ideia de movimento, quiçá a reforça. [...] As anotações de seu Joaquim sabiam dessa força, as memórias de José não sabem. (BRACHER, 2004, p. 109).

O pai fora uma figura extremamente forte e marcante não apenas para Gustavo, mas para toda a família. Além da honestidade e sensatez, seu Joaquim era reconhecido por sua relação com as palavras, tanto na fala quanto nos textos para o sindicato, e até mesmo na música, era sucinto e objetivo, inúmeras vezes silencioso.

\section{Silêncios}

Outra forma de vazio que encontro nesse romance é caracterizada pela supressão de elementos da história que deixam sem explicação comportamentos e condutas dos personagens, nomeio esses vazios de "silêncios" e escolhi três deles para analisar.

Podemos começar a compreender os inúmeros não ditos no âmbito familiar pela música de seu Joaquim. Sua paixão pela flauta, a concentração e a cerimônia com que tratava os momentos de ensaios, tanto a sós quanto com os amigos do choro, indicam sua forte ligação com a música que, como ele, era também silenciosa: “Joaquim Ferreira não era grande leitor e seu choro não admitia palavras" (BRACHER, 2004, p. 135).

Quando jovem, Joaquim fora músico profissional, mas com a constituição da família e a baixa rentabilidade, desistira de fazer da arte seu ofício, passou a trabalhar nos Correios, participando ativamente do sindicato e reservou para sua paixão apenas 
as tardes de sábado, momentos em que abria a caixa preta e ensaiava concentrado, aguardando a chegada dos amigos que vinham tocar o choro.

Gustavo admirava o pai e apreciava esses seus momentos:

\begin{abstract}
Nessas horas eu fingia ler um livro deitado no chão de tacos e controlava o movimento de minha cabeça e dos pés para que ele não percebesse que acompanhava a música e o prazer que sentia. De alguma forma sabia que o pai não gostaria e temia que nunca mais tocasse perto de nós. (BRACHER, 2004, p. 44).
\end{abstract}

A ressalva do garoto em achar que o pai não gostaria de vê-lo empolgado com o som originava-se de vários não ditos ao longo dos anos e, sobretudo, do que dona Joana cultuava nos filhos: ao mesmo tempo admiração e temor pelo pai. Aprenderam a admirá-lo por sua profundidade e sensibilidade, transmitidas pela música, mas aprenderam também a temê-lo de tal modo que às crianças restava precaverem-se daquele ser silencioso a fim de não dar-lhe motivos para irritação, sob o risco de despertarem sua fúria.

A seguinte passagem em Bracher deixa bem claro que esse temor de Gustavo fora alimentado por silêncios:

Não consigo me lembrar de qualquer palavra dos meus pais sobre não mexermos na caixa preta ou não pedir ao pai que nos tocasse algo. Sabíamos que esse assunto não deveria ser tocado, assim como a caixa preta. [...] Talvez nunca nos tenha dito, mas sabíamos, pois nunca pedimos a ele que tocasse, apesar de, por diversas vezes (isso me lembro bem), ter desejado fazê-lo. (BRACHER, 2004, p. 43-44).

Por que ninguém da família tocava no assunto da música com seu Joaquim? Por que Gustavo, apesar de gostar tanto de ouvir o pai tocar, não podia deixar transparecer que se empolgava com o som, ou mesmo por que não pedia ao pai que tocasse para ele, já que desejava ouvi-lo diversas vezes? Em que momento da história dessa família houve a interdição sobre este assunto? Por que ninguém se lembra disso? Qual a razão dessa interdição velada? São todas perguntas sem respostas. A única resposta é o próprio silêncio. Para essa família o não dito sobre a música do pai era uma consciência de que não se devia tocar nesse assunto, nem manifestar sentimento algum ao ouvi-la. Esse silêncio tem um significado que ultrapassa o sentido e que só é possível porque não é explícito. 
O filósofo Kovadloff (2003) desenvolveu um estudo sobre o tema e designou duas formas de silêncios. Há uma que funciona como um mascaramento, que oculta ou nega algo que poderia ser explícito, é, portanto, algo que foi silenciado. Há outra forma, para a qual não há equivalência em palavras, é um fundo irredutível, é o silencioso, que ele nomeia de silêncio primordial. Para este que não designamos podemos, no entanto, reconhecer e analisar através dos sujeitos que o protagonizaram, examinando a conduta de quem foi por ele subjugado.

Em Não falei há um silêncio primordial, há um fundo irredutível que não se pode nomear, mas que se pode ouvir por via alusiva, como afirma Kovadloff (2003). A alusão neste caso é o próprio romance. Com a representação de cada personagem e com os episódios em que os fatos, sentimentos ou os sujeitos foram silenciados obtemos vestígios sobre a conduta de cada uma das pessoas dessa família e sobre a forma que se relacionavam entre si e com os outros.

Concatenando os indícios visualizamos a trama familiar e compreendemos profundamente o impacto dessa natureza silenciosa sobre cada um dos indivíduos, podemos habitar ${ }^{2}$ esse romance e assim suportar a insondável densidade desse silêncio.

Para isso é preciso observar atentamente os indícios que nos são colocados e analisar os episódios silenciados. Eis aqui o segundo silêncio que analiso, o silêncio da família. Logo nas primeiras páginas, ao relatar a aproximação de Armando com seus entes, Gustavo nos adianta um dado importante:

Passaram a ser as almôndegas do Armando, o arroz do Armando, a mesma coisa boa de sempre, mas com dono certo. Eu, José, o pai ou Jussara não tínhamos nossos pratos, apesar de comermos com gosto, mas acho que o elogio não fazia parte da nossa linguagem, talvez por isso. (BRACHER, 2004, p. 12).

A comida de dona Joana era apreciada pela família, comiam com gosto, mas não falavam sobre ela, não a elogiavam para que a cozinheira soubesse e se alegrasse a ponto de nomear pratos para seus próximos. Armando teve esse privilégio porque,

2 Para o filósofo Paul Ricoeur, o leitor habita o texto literário quando conhece e compreende profundamente a obra, sendo assim capaz de relacionar questões distintas à problemática da história e fazer inferências com as mais diversas áreas do conhecimento. (RICOEUR, 2007). 
como o próprio Gustavo descreveu ao analisá-lo páginas depois, ele tinha a sedução como estratégia de sobrevivência, por isso era querido e bem relacionado onde quer que fosse.

Ademais, observo que o narrador não afirma simplesmente que não elogiavam a comida da mãe, ele afirma que o elogio não fazia parte da linguagem daquela família. Isso denota um problema mais profundo, já que o elogio é uma expressão verbal para mostrar a quem produziu algo o reconhecimento por seu feito. Essa primeira passagem, portanto, já nos adianta que nessa casa, além do silêncio, havia pouco espaço para o reconhecimento, para a valorização de cada integrante.

Como a linguagem da família era escassa, a comunicação, sendo inerente à espécie humana, se dava de várias outras formas, como podemos captar neste trecho do livro de José:

\footnotetext{
Assim eram as massas da minha casa, tudo caminha e modifica-se, fala e ouve. Começo a falar tarde, e, diferente de meus irmãos, tenho muita dificuldade para aprender a escrever. A casa não era de muitas palavras, falava de outras formas. A escada dizia quem chegava ou saía, o cheiro de cada cliente dizia do tipo de trabalho da mãe, o jeito de a porta abrir à noite para o meu pai determinava a hora em que iríamos para o quarto. (BRACHER, 2004, p. 58).
}

A narrativa desse irmão consegue verbalizar o que não era dito na casa, mas era percebido, sentido por ele. A falta da palavra imprimira em cada membro da família uma marca, mas talvez em José ela deixara cicatrizes mais profundas, a ponto de fazê-lo escrever sobre isso. Ele tivera a necessidade de descrever detalhes dessa vida em família, de seus membros, da casa, de situações vividas e de elementos rotineiros muitas vezes esquecidos ou considerados irrelevantes, mas que para a agudez de sua sensibilidade eram importantes e lhe faziam compreender o mundo à sua volta. Uma reflexão de Kovadloff nos ajuda a compreender o sentimento de José para com os detalhes rotineiros - "E o que é a rotina, a não ser essa opacidade do coração que aniquila toda relevância?"' (KOVADLOFF, 2003, p. 24).

Naturalmente, num espaço em que o silêncio impera a imaginação trabalha. Sem ter como saber o que o outro pensa, por falta das palavras, cada ser o imagina a fim de costurar o fio dos acontecimentos diários. Nessa família, o pai, além de ser 
o maior provedor, representava o bom senso, o equilíbrio e a sensatez. No entanto, o fato de ser de poucas palavras e, consequentemente, de não deixar claros seus julgamentos sobre as miudezas diárias, tornou seu silêncio um elemento opressor e ele uma figura a se temer. Várias passagens do texto evidenciam esse temor por seu Joaquim, especialmente alguns trechos do livro de José.

Diferente das mulheres, o desejo de meu pai não evoluía em palavras, não olhava o seu rosto e voz não havia, mas sentia apertando minha cabeça enquanto olhava seus sapatos empoeirados, o barulho de sua braveza e decepção. (BRACHER, 2004, p. 99).

Talvez José seja quem se sentiu mais oprimido pelo silêncio. Sabia que era diferente dos irmãos e sua sensibilidade tornara-o mais suscetível a toda sorte de ofensas, declaradas ou não. Também lhe era difícil suportar a decepção que o silêncio do pai lhe sugeria ter despertado em algumas ocasiões. No episódio em questão, seu Joaquim ordenara-lhe que subisse numa árvore para pegar um galho à vizinha, mas o filho ficou paralisado, não conseguiu sequer tentar fazer o que lhe fora ordenado, embora por diversas vezes já tivesse subido naquela árvore. O pai nada fez, nada disse, mas José sentiu-se extremamente humilhado pela situação e sufocado por seu silêncio.

Após a leitura deste trecho do livro do irmão, Gustavo reflete sobre o peso que teve para José a ausência das palavras:

Quem sabe? Talvez para José tivesse sido menos humilhante receber uns cascudos do que o silêncio de seu Joaquim. Quem sabe? (BRACHER, 2004, p. 102).

A reflexão de Gustavo cabe perfeitamente, por analogia, à sua própria situação em relação à suposta delação de Armando. O "não falei" do nosso protagonista é o terceiro silêncio que analiso e que, após o caminho percorrido até aqui, pode ser compreendido com mais clareza e profundidade.

A marca da traição é mais leve que sua ausência. Mas tive que lidar com as duas misturadas, como se uma só. Assumi, é verdade, caleime, recusei responder à acusação jamais formulada e eternamente sussurrada. Não era apenas nojo, também isso, é verdade, um asco violentamente físico a cada vez que autoria do crime aparecia fantasmagórica num olhar, num comentário, nas esquivas e ausências dos que supunha amigos. [...] Qualquer pessoa transformava-se no portador da acusação - traidor. (BRACHER, 2004, p. 71). 
É sobre a ausência de Armando que Gustavo fala neste trecho, somente a falta do amigo-irmão lhe causava maior dor que a acusação de tê-lo entregue aos militares. Lidar com as duas - traição e ausência - como se uma só decorre da culpa que ele próprio sentira pela morte do amigo, uma culpa justa e verdadeira, não por ter delatado, pois isso deixou claro que não fez, mas por ter sido o motivo da captura de Armando.

Em algumas passagens do texto Gustavo explica que ficara preso por longo tempo e apanhara muito por não conhecer a linguagem e os códigos dos movimentos de resistência. Não conhecia os artifícios da entrega a prêmio, ou seja, não sabia que havia um manual de conduta em que informações delatadas a cada período de prisão eram admitidas e mesmo planejadas pelos grupos, a fim de ganhar tempo e despistar os torturadores. Foi para salvar o amigo e a irmã que Armando se expôs e foi preso, foi por causa da prisão de Gustavo que ele pôs-se a campo quando deveria recolher-se, procedimento padrão caso o preso fosse simplesmente um companheiro da organização. Mas não, o preso era seu amigo, seu irmão, seu cunhado. Por isso o protagonista sente-se culpado: "Armando fora entregue por minha causa, não por minha boca, mas isso não fazia diferença." (BRACHER, 2004, p. 117).

Esse sentimento de culpa o fez assumir, calar-se, recusar-se a responder à acusação. Compreendendo o silêncio como uma forma de discurso e, além disso, sabendo que o silêncio é extremamente presente em sua história familiar, foi esse o único recurso que Gustavo conseguiu lançar mão para expressar a indignação pela suspeita de si. Negar ou tentar explicar seria vil a seu ver, pois aviltaria a hipótese de a delação ter ocorrido e o que mais lhe incomodava depois da falta do amigo era pensarem que ele fora capaz de entregá-lo.

Um elemento importante também a se observar é sua afirmação de que a acusação jamais fora formulada, mas eternamente sussurrada. Ele não ouviu acusações, mas como fora acostumado desde muito cedo a ler os silêncios, as sentiu, as percebeu fantasmagóricas nos olhares, nos comentários, nas esquivas e ausências das pessoas. Ao longo de todo o romance as únicas passagens em que a acusação ficou mais clara estão no desabafo da sogra antes de cometer suicídio “[...] Armando confiava em 
você mais do que em mim mesma"3. E numa fala de Luiza, uma das mulheres de Armando que estava com Eliana em Paris "[...] apesar de Armando você continua um dos nossos, [...] Eliana morreu sem saber, não se preocupe"4.

Foi por meio dessas falas escutadas logo após sua saída da prisão que Gustavo concluiu ser consenso entre todos que ele havia entregue o amigo, por isso relata que qualquer pessoa transformava-se no portador da acusação. Junte-se à essas acusações indiretas o sentimento de culpa do narrador e podemos notá-lo silencioso, fechado em seus próprios pensamentos, lendo em qualquer face ou comportamento de outrem o julgamento a que ele próprio se condenou, talvez até por expiação. Neste complexo caso, não só ele fez do silêncio sua linguagem como admitiu o silêncio dos outros como uma linguagem acusatória. Talvez também para ele tivesse sido menos humilhante receber acusações diretas e penalidades claras do que o silêncio de todos. As acusações diretas poderia rebater, argumentar ou mesmo sobre elas transbordar sua ira. Se houvesse sido penalizado, se, por exemplo, não o tivessem deixado "continuar diretor de escola"5 ele poderia se comprazer de ter sido injustiçado e talvez isso o ajudasse a sentir que expiava a culpa que ele mesmo se atribuiu.

Por fim, depois de perpassar suas lembranças, já velho, ele mesmo consegue questionar essa leitura que fizera do silêncio alheio e reflete: "talvez jamais alguém tenha me considerado um traidor, a não ser eu mesmo."6 e "qualquer bater de asas de borboleta no Japão teria ocasionado a formação da história de minha traição dentro de mim"7. Tal questionamento de concepção neste ponto nos leva a retornar ao conceito de preenchimento dos vazios pelo leitor de Wolfgang Iser. É como se Gustavo, ao visitar, ao "ler" sua própria história pudesse então, depois de adquiridas tantas experiências, modificar e multiplicar as possibilidades de representações de seus vazios e corrigir suas projeções sobre ela. Aceitando sua própria história Gustavo passou a ser capaz de suportar o silêncio primordial que perpassava sua vida.

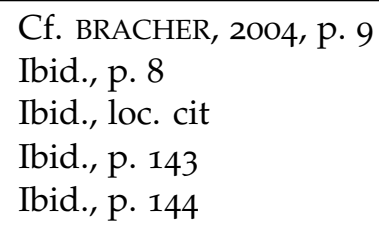




\section{Ausências}

O silêncio primordial não pode ser designado, é inominável, ele é sentido, é perceptível nas sutilezas, mas não há equivalência em palavras para determiná-lo. A única forma de ter ciência dele é reconhecê-lo por via alusiva, nas palavras não fundadas num ato voluntário, mas sim frutos de um arrebatamento, como coloca Kovadloff (2003). Pois bem, até aqui reconhecemos esse silêncio maior do romance em alguns episódios de silenciamento, em expressões deixadas inacabadas e em palavras que poderiam ter sido ditas mas não foram.

Gustavo sofreu muitas perdas de pessoas queridas no período conturbado que foi de sua prisão a alguns meses depois. Perdeu, sobretudo, parte de si com a tortura e o medo que ela lhe impusera por longo tempo; também a presença de pessoas que lhe eram muito caras, como Eliana, Armando e seu Joaquim que, mesmo ainda vivo, modificara-se após a prisão do filho — "talvez ele tivesse sido fechado pelos militares" (BRACHER, 2004, p. 141) - explica o protagonista. Todas essas perdas impuseram grandes ausências para Gustavo, no sentido de sentimento de dor pela falta dessas pessoas, de atividades que fazia com cada uma delas, tanto que incorporou alguns hábitos, talvez para tentar suprimir a falta.

No entanto, há algo mais profundo que a simples falta, é um arrebatamento de dor da ordem da impossibilidade. São ausências que estão expressas pela linguagem, mas que, por meio da arquitetura das palavras, pela impossibilidade de contar a dor sentida, sugerem uma lacuna psíquica inenarrável, um sentimento de dor tão profundo que vai além da tristeza justificável pelos trágicos acontecimentos.

Há um trecho extremamente sensível em que Gustavo recorda-se e distingue Eliana de Elaine. Esta última era como um heterônimo da esposa, alguém que só existia entre os dois, uma face de Eliana que era compartilhada com Gustavo e que os tornavam íntimos, cúmplices de um segredo. Elaine era a face frágil daquela mulher, quem precisava desesperadamente do amado, sentia muito frio de noite e precisava se enroscar em suas pernas e repousar a cabeça em seu peito para se aquecer e falar baixinho de seus medos. Num momento reflete sobre a ausência delas em sua vida: 
Eu ouço Eliana nitidamente, não me assusto quando, de noite na cama, sua voz me chama. Não ouço Elaine, quem me visita é a ausência de suas pernas e do peso de sua cabeça. [...] Meu Deus, que tristeza, não pude abraçá-la, ela não viu meus olhos, não tinha calor nem mãos no telefone. Essa impossibilidade nunca vai me deixar. (BRACHER, 2004, p. 107).

Apesar de ausente Eliana é presentificada na vida de Gustavo por meio do que tinham em comum, o trabalho com as palavras, a estima por Armando, o pender para o certo. A relação com Elaine não se dava pelos aspectos em comum, mas pelas diferenças, pela necessidade que ela tinha do calor dele para sobreviver. Eliana/Elaine morreu em Paris de pneumonia, morreu pelo frio, e é justamente este aspecto que o fez sentir de tal forma a dor por sua perda que apenas sua ausência se faz presente.

A lacuna psíquica da imensa dor que o acometeu, naquele momento, e por toda a sua vida - por não poder aquecê-la na hora em que ela tanto precisava - fica sugerida pela forma como o período foi construído e pela escolha das palavras: "quem me visita é a ausência de suas pernas e do peso de sua cabeça." (BRACHER, 2004, p. 107). Elaine não era presença, era sensação.

De que maneira um autor pode transmitir uma sensação como essa a seu leitor? Como expressar o arrebatamento que ela causou no próprio personagem? Sem dúvida há leitores que alcançarão essa sensação, de acordo com sua receptividade do texto. Importa observar que há uma estratégia textual adotada para construir um efeito estético nessa obra, mais especificamente nos trechos de vazios. A estratégia está impressa no texto, mas a completude do efeito depende do leitor, no sentido em que Iser (1979) nomeou de papel do leitor.

Nesse caso, o papel do leitor assume um caráter transcendental, ao traduzir essa estrutura textual para seu campo de experiência, havendo uma identificação pela situação, ele pode compreender e experimentar dor semelhante à do personagem.

Há outra passagem que considero de extrema sensibilidade e na qual observo uma ausência de mesma natureza, porém com uma estratégia textual diferente: a paradoxal narrativa da impossibilidade de narrar a dor sentida. Trata-se de quando Lígia era criança e Gustavo costumava levá-la para passear em cemitérios. A menina 
desenvolvera um gosto por esses passeios e criara suas próprias cerimônias para a ocasião, imitava os visitantes, inventava histórias para as pessoas das lápides e dançava entre os túmulos tornando-se a bailarina dos mortos, enfim "o cemitério foi sua primeira biblioteca" ${ }^{\prime}$. Certa vez perguntou ao pai porque a mãe não tinha um túmulo, resolveram então desenhar a giz uma lápide para Eliana no jazigo da família. Isso reconfortou os dois e foi uma forma de aproximar mãe e filha.

Um dia Lígia levou uma amiga para esse passeio e ela lhe contou que havia pessoas mortas embaixo da terra, a menina duvidou e buscou o olhar do pai para confirmar a informação, encontrou nele uma tristeza séria e seu riso se transformou. Só então compreendeu o conceito de morte como finitude e apodrecimento da carne, "mas eu estou aqui Lígia, estarei sempre, meu olhar tentou completar, mas ela já não me enxergava"9 . Foi como se, ao confirmar a verdade sobre os mortos, ele tivesse tirado a inocência de Lígia e traído as cerimônias no cemitério, algo partilhado apenas pelos dois e que era a verdade para a menina até então. Tendo isso constatado e lamentavelmente sentido por Gustavo ele conclui: “Mas onde direi da expressão de Lígia ao ver seu primeiro enterro? Quando seu entendimento finalmente uniu morto e corpo, lembrança e apodrecimento"10.

A construção desse período é de uma sensibilidade tocante, o protagonista chama o leitor a aquiescer-se com sua impossibilidade e contrapõe ao apodrecimento a lembrança, numa alusão à manutenção da vida dos que se foram nas lembranças dos que ficaram. Este pequeno trecho implica um paradoxo e uma discussão filosófica.

É paradoxal Gustavo narrar que não tem como contar sobre o sentimento da filha ao ver seu primeiro enterro, pois em toda a preleção antes de chegar a esse ponto da história ele esteve contando sobre a íntima relação dos dois nas visitas aos cemitérios, coloca em palavras o que significava para cada um aqueles momentos. Após o rompimento do fator de cumplicidade ele perde a voz, não consegue mais transmitir seus sentimentos, passa a marcar na linguagem algo que ele não tem como dizer, a dor é tão visceral que ele opta por expressar sua impossibilidade de traduzir 
aquilo em palavras colocando a questão para o leitor, chamando-o a partilhar com ele essa impossibilidade: "Mas onde direi...?".

A discussão filosófica suscitada é a da impossibilidade de transmissão da lembrança a outrem. Segundo Ricoeur (2007, p. 134), há três sujeitos de atribuição da lembrança ${ }^{11}$ : eu, os coletivos e os próximos; a situação em questão decorre de um fenômeno da memória individual de Gustavo. Apenas ele lembra-se desta maneira, pois fora o único a experimentar naquele acontecimento o protagonismo de um pai presenciando a perda da inocência da filha sobre a morte. Se pudéssemos ter o relato de Lígia sobre o mesmo episódio certamente teríamos outra história, já que seu ângulo no acontecimento fora outro.

Neste caso há uma lembrança cuja aderência do "quem" se lembra ao "que" se lembra é tão tenaz que dificulta a transferência da lembrança de uma consciência a outra. Por causa da história pregressa que ele partilhou unicamente com a filha e também por causa de seu ângulo singular nela, aquele instante em que Lígia viu seu primeiro enterro, já com a consciência de morte que adquiriu, ficou gravado de tal forma no psíquico de Gustavo que ao lembrar-se do episódio ele lembra-se de si mesmo, da sensação única que ele experimentou e que não pode transmitir a ninguém mais. Segundo Ricoeur, trata-se de uma minhadade, termo que ele cunhou para designar essa aderência do quem se lembra ao que se lembra.

Se não há como transmitir sua lembrança a outros indivíduos, pela construção textual há como suscitar no leitor lembranças individuais que o levem a se aproximar do sentimento do protagonista. Assim, com a possível identificação em diversos pontos da narrativa, nós leitores vamos aceitando o romance, preenchendo-o de significados e compreendendo seu silêncio primordial.

Percebemos, por fim, que o "não falei" de Gustavo não se refere somente ao episódio sobre a morte de Armando, mas à sua maneira de ser e de reagir ao que lhe acontece. O personagem principal desse romance não fala em diversas ocasiões de sua vida por ser o silêncio uma linguagem natural para si, algo apreendido desde a infância, pela conduta de sua família. Gustavo aceita e interpreta o silêncio e os

$\overline{11}$ Retornarei ao tema dos sujeitos de atribuição da lembrança na página 31, segundo capítulo. 
vazios dele decorrentes, mas tem dificuldade em se expressar verbalmente, tanto que a própria narrativa de Não falei é uma história que ele formula somente para si mesmo. Ao longo de todo o romance é como se estivéssemos dentro de seus pensamentos, acompanhamos o vai e vem das lembranças, embaralhadas como elas lhe surgem, atravessadas por pensamentos cotidianos, por interrupções de ordem prática da rotina diária e, ao final, percebemos que Gustavo nunca falara nada daquilo, nem mesmo para Cecília, a quem havia prometido uma entrevista: “Eu falaria isso, Cecília, se fosse possível." (BRACHER, 2004, p. 148). 


\section{Lembrança quebrada e lembrança certa}

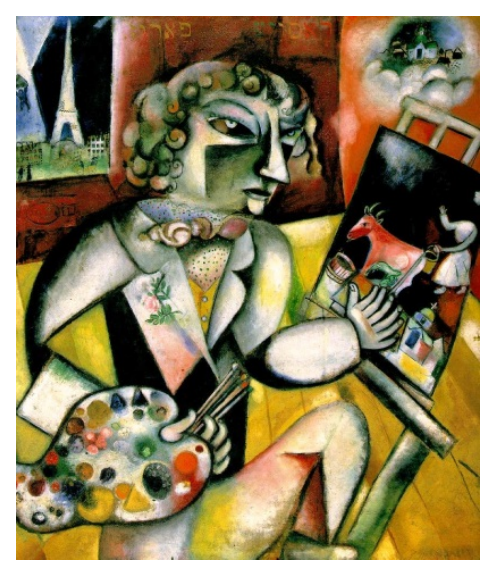

- Marc Chagall, Autoritratto con sette dita, 1913.

Na tela de Chagall, observamos que o artista pinta a si próprio e de maneira não linear. Própria das tendências cubistas, a sobreposição de planos vai além da técnica e avança para a relação espaço-tempo em que momentos diferentes da vida do pintor são retratados numa mesma superfície. Empregando-se o princípio do cronotopo bakhtiniano (BAKHTIN, 1981), notamos a indissociabilidade desses dois elementos, expressa também nas artes plásticas. Em autorretrato, Chagall está pintando uma obra anterior realizada por ele-Para Rússia, para burros e para outros, de 1911-1912 — sendo o elemento do tempo passado. A imagem da torre Eiffel vista através da janela é o componente do tempo presente. Uma nuvem simbolizando o pensamento pode ser compreendida como a representação do futuro, expressando um desejo de retorno àquele lugar, Vitebsk, sua cidade natal, na Bielorrússia.

A convergência da pintura com a presente pesquisa se dá pela relação tempoespaço e pelo vínculo com o tema da memória. Em Não falei também se observa a representação de três tempos na espacialidade da obra. No presente da narrativa, o resgate das lembranças e a expectativa do futuro constituem uma situação de reflexão em que, justamente a confluência dos tempos e a avaliação de suas relações com os espaços, resultam num desfecho surpreendente.

De que há lembrança? De quem é a memória? São duas perguntas que o filósofo Ricoeur (2007) lança em sua obra A memória, a história, o esquecimento, refle- 
xões que considero inquietantes e que orientam minha pesquisa. Aplicadas ao caso particular de Gustavo, as duas questões suscitaram-me ainda uma terceira: como se lembra?

Cada pessoa é única e as lembranças que é capaz de resgatar também o são. A memória humana não consegue reaver todos os momentos vividos e seus detalhes, como aconteceu ao personagem Funes ${ }^{1}$, criado por Jorge Luis Borges. Temos algumas lembranças rasas, de fácil acesso; outras que, com um exercício de rememoração conseguimos resgatar; mas há ainda aquelas das quais sequer temos conhecimento de sua existência até que algo externo a nós as resgata do palácio escuro de nossa memória, como veremos mais adiante.

Duas pessoas que partilham um evento não se recordarão dele da mesma maneira, pois as diferentes visões de um mesmo ocorrido se corrigem e completam a cena ${ }^{2}$. Por isso Ricoeur distingue três sujeitos de atribuição das lembranças: o eu, o coletivo e os próximos. A memória coletiva 3 e a dos próximos completam a memória de um indivíduo e também atestam a existência dele. Ninguém consegue se recordar de seu próprio nascimento, por exemplo, são as pessoas mais próximas que detém essa lembrança. Quando alguém morre, sua existência só acaba quando morre também a última pessoa que se lembra dele 4 . Algumas de nossas lembranças só ganham sentido dentro de um contexto cultural coletivo, por exemplo, as celebrações de tradições como as festas populares regionais do Brasil, os rituais indígenas, as celebrações judaicas, dentre tantos outros. Com essas distinções temos ferramentas para analisar de quem é a memória na obra em questão.

1 Refere-se ao personagem Irineu Funes que de tudo se recordava. Do conto Funes, o memorioso, escrito em 1942 por Jorge Luis Borges. (BORGES, 2002).

2 Sobre a nossa impressão poder apoiar-se em nossas lembranças e também na dos outros, Halbwachs (1990) afirma ainda "[...] em realidade, nunca estamos sós. [...] porque temos sempre conosco e em nós uma quantidade de pessoas que não se confundem.".

3 Compreendo a memória coletiva na concepção de Halbwachs (1990).

4 Neste ponto recordo-me do narrador de O enteado, romance de Juan José Saer. Sessenta anos depois de viver uma experiência marcante com uma tribo antropófaga, o homem, já velho, escreve sobre aqueles indígenas como um dever de memória, para dar testemunho de sua existência, pois já haviam sido dizimados. Numa análise dessa obra, Almarza (2012) assinala os passos do necessário percurso do reconhecimento por que passou esse homem e conclui que ele "[...] em consequência desta ação de se narrar, medita sobre si mesmo e assim completa seu ipse". Ocorre, portanto, algo semelhante com o personagem de Não falei que, ao narrar-se também medita sobre si e completa seu ipse com o reconhecimento. 
O narrador de Não falei tem 64 anos, está se aposentando e preparando sua mudança para uma cidade do interior. No entanto, para fechar esse ciclo e entrar num outro, questões práticas e burocráticas que demandam tempo lhe fazem viver o que chama de "entreato da vida", momento no qual visita sua memória e reconstitui sua trajetória. Alguns momentos vividos o marcaram de tal forma que Gustavo sabe não ter como transmiti-los a ninguém, foram afecções impressas em sua alma. Sobre outras situações ele encontra na memória coletiva elementos que complementam suas lembranças, como no caso das torturas sofridas na ditadura e das táticas de sobrevivência dos grupos de resistência; bem como sobre o tratamento dado aos velhos em nossa cultura e a sensação de morte em vida que a aposentadoria proporciona; também sobre os rumos da educação no Brasil pós-ditadura. Pela memória dos próximos, Gustavo tem gratas surpresas, tanto pelo romance do irmão que lhe fornece meios de identificar elementos que lhe foram atribuídos, mas que não lhe pertenciam de fato, quanto, e, sobretudo, pela fala do pai, de que se recorda apenas ao final do trabalho de rememoração.

O desenrolar de seu trabalho vamos conhecendo aos poucos. De que maneira Gustavo se lembra é um elemento interessante a se observar. O enredo acompanha sua memória, desenrola-se no mesmo ritmo em que suas reflexões se colocam e com o mesmo ordenamento que suas lembranças afloram, ou seja, sem uma sequência cronológica e sem um encadeamento lógico, de modo embaralhado, quebrado, como ele mesmo nomeia e como se dá, de fato, o surgimento das lembranças, sobretudo a dos velhos 5 :

Ela [Cecília] quer a minha idade. Fareja por resquícios daqueles anos na fala atual dos homens velhos. [...] Eu falei a ela que não me lembrava de quase nada e ela disse que queria isso também, a lembrança quebrada, um embaralhamento do que sobrou visto de longe, quase sumindo no meio do tal vazio agressivo. (BRACHER, 2004, p. 19).

De fato, as lembranças de Gustavo surgem fragmentadas, embaralhadas, e a arquitetura do texto nos envolve nesse modo de recordar. Numa mesma página ele conta sobre como beijou Eliana pela primeira vez, sobre relatórios que fez para a

5 Baseio essa afirmação nos estudos sobre a memória dos velhos de Ecléa Bosi em Memória e sociedade. Cf. BOSI, 1994. 
secretaria de governo, faz uma reflexão filosófica sobre a necessidade da educação, relata o percurso do homem da infância à velhice e à morte e retoma a descrição de Eliana (BRACHER, 2004, p. 46).

Noutras vezes, a construção do texto mostra-se mesmo caótica, sem nexo, como em: "Eu mostro a ela [Marta] como achar tatu-bolinha e estourar as sementinhas de maria-sem-vergonha. Queria que Lígia fosse para São Carlos. O cachorro de Alexandre solta pêlos e espirrarei a noite inteira." (BRACHER, 2004, p. 80). Tudo isso embaralhado assim mesmo, mas com um fio condutor tênue, que perpassa o romance, nos fazendo sentir como se estivéssemos na própria consciência do narrador e nos permitindo juntar as peças da maneira necessária para compreendermos a complexidade de sua história.

Um evento traumático como sua terrível tortura, seguido pelo assassinato do cunhado, admitido por todos como ocasionado por sua suposta delação; posteriormente, a morte da mulher longe de si e, por fim, a culpabilidade que lhe foi atribuída pela fala da sogra com seu suicídio logo em seguida. Diversas situações provocaram em Gustavo um estado de fuga, uma suspensão da realidade, traduzida em palavras por ele em alguns trechos da narrativa. Por exemplo, o seguinte:

Curioso, na minha cabeça uma parte da realidade, de seu fluxo, interrompeu-se a partir de setenta. [...] Literatura, poesia, cinema, artes plásticas, teatro, nada aconteceu por dez anos. A partir de oitenta a névoa se dissipa e algumas formas são perceptíveis mas num reino distante que não alcanço e nem tenho muito interesse, apesar de me fazer falta." (BRACHER, 2004, p. 84-85).

Talvez Gustavo tenha vivido num estado melancólico ${ }^{6}$ sua vida pessoal por todo o tempo após ter saído da prisão, sendo que, apenas no entreato da vida, no momento em que já amadurecido e com o tempo contando a seu favor, dispôs-se a olhar para o passado, visitar sua memória e entrar em contato com objetos portadores de lembranças. Nesse momento em que narra sua história - no qual suas vivências, experiências e dores são pronunciadas em palavras, levando-o a travar consigo mesmo um discurso - é que Gustavo vive de fato o seu luto.

6 Compreendo o estado melancólico a partir de características do humor melancólico, expostas por Ricoeur (2007, p. 88), designadas pelo antigo sistema dos quatro humores da medicina grega: humor melancólico; humor sanguíneo; humor colérico e humor fleumático. 
Segundo os estudos de Freud (1946 apud RICOEUR, 2007, p. 85), melancolia e luto não podem ser entendidos como iguais, pois há investimentos afetivos diferentes em cada um que demandam modalidades de trabalho distintas. O luto requer tempo, é feito dentro do presente, talvez por isso seja um processo mais doloroso já que no presente o elemento está perdido, assemelhando-se ao exercício da lembrança. Ao fim do período de luto, o ego, antes preso ao objeto amado perdido, encontra-se novamente livre.

O trabalho do luto, bem como o da lembrança, embora sejam difíceis e dolorosos, são libertadores. Já o da melancolia é resistente e configura-se pela compulsão de repetição. O indivíduo substitui a lembrança por esse duplo fenômeno, diminuindo seu ego, desvalorizando-o, tornando-se vítima da própria condenação (RICOEUR, 2007, p. 86). Gustavo sabe que não delatou o cunhado, mas, de alguma maneira, até para ele obscura, sente-se responsável pela morte do amigo, pelo falecimento da esposa à distância e pela decadência do pai. A resistência frente a esses fatos leva Gustavo a escutar nitidamente a voz de Eliana, a sentir profundamente sua ausência e a incorporar hábitos do amigo e do pai, fazendo-os sempre presentes em sua vida e repetindo compulsivamente essas perdas.

A narrativa de Gustavo parte das situações a que estava submetido no momento de rever sua vida. Com o esforço de levar sua memória à linguagem, seu estado melancólico presente até então no âmbito pessoal dá lugar a um trabalho de lembrança com o qual pode viver o luto e ressignificar seu passado a fim de reconciliar-se com este. Importante assinalar que esse estado melancólico é vivido por Gustavo apenas no plano pessoal, já que profissionalmente ele torna-se bastante ativo, podendo-se concordar com o próprio narrador de que seu trabalho fora sua fuga:

O estudo, a pesquisa e a linguística me salvaram dessa letargia e ali-
enação, em que só o trabalho importava, mobilizar as pessoas para a
ação, [...] Depois afundei-me no estudo, na universidade. (BRACHER,
2004, p. 86).

Sua conduta no trabalho nos é apresentada por ele repleta de questionamentos ao sistema educacional, aos responsáveis pelo ensino e até a si e às suas próprias condutas. O caso de Benício (BRACHER, 2004, p. 51-55) ilustra bem esse seu comprome- 
timento e fica evidente que seu olhar para os alunos ia além de sua condição escolar. Considerava também seus processos em cada fase etária, as relações familiares de cada aluno e seus históricos de convívio social. Com Benício ele investe em diversas abordagens e por longo prazo, mobiliza os professores e a família do rapaz e consegue tratamento psicológico, tudo para desestabilizá-lo e tirar dele o papel de palhaço da turma, que havia agarrado com muito apego. Resgatou esse aluno da mediocridade e mostrou a ele que tinha meios de ser melhor.

A riqueza de detalhes sobre as relações e análises que Gustavo faz entre a escola, os alunos e suas famílias nos coloca diante de sua profunda reflexão sobre a capacidade revolucionária da educação, sobre o sistema de ensino brasileiro e suas transformações após o período da ditadura. Também o que a escritora a quem ele concederá a entrevista chama de "vazio agressivo" entre os professores, que a assusta e instiga.

Esse vazio por ela constatado instaura-se quando a educação deixa de ser vista como um fim, como um objetivo por si só, e passa a ser encarada como um meio, uma ferramenta para se conseguir melhor posição econômica. Quando o conhecimento e a capacidade reflexiva e questionadora que ele proporciona deixam de ser a finalidade, deparamo-nos com uma educação conteudista, aquela que, longe de desenvolver a capacidade crítica, apenas serve como meio para se alcançar o sucesso profissional, compreendendo este como sinônimo de progresso econômico. No período ditatorial brasileiro era essa a grande meta do regime, desenvolvimento econômico e nenhum questionamento às suas imposições, por isso as salas de aula das escolas e universidades, berços do pensamento crítico, foram tão controladas.

As reflexões de Gustavo ao longo do romance, a exposição de suas ações no caso de Benício, os trechos de cartas e relatórios sobre sua avaliação da educação enquanto fora consultor do Secretário, os trechos de suas anotações sobre conversas entre mães de alunos e professores, em todas essas ocorrências relatadas por ele podemos constatar que se deparou inúmeras vezes com ausência de pensamento crítico por parte dos envolvidos com a educação e com o ensino no período pósditadura, sendo essa uma das causas do tal "vazio agressivo" detectado por Cecília. 
Para Gustavo, sua entrega ao trabalho, sua dedicação no desempenho da função de diretor com um olhar reflexivo sobre os processos educacionais e seu empenho nos cursos de recapacitação de professores, foram formas que encontrou de transmitir e perpetuar sua visão de educação, mas foram também uma válvula de escape. $\mathrm{O}$ trabalho tornou-se um refúgio de suas dores e um antídoto para a melancolia, como nos explica Ricoeur7.

Portanto, a condição de melancólico do narrador apenas no plano pessoal corrobora para o entendimento que Ricoeur tem desse temperamento e que, diferentemente de Freud, que delegou a melancolia aos cuidados da psiquiatria, defende que tal característica, longe de ser uma patologia é até uma excepcionalidade, tem algo de genialidade, visto que vários grandes pensadores de diferentes áreas apresentaram esse temperamento. Segundo o filósofo francês, é justamente a ambivalência da melancolia entre ideia de doença e ideia de caráter ou temperamento que promove o equilíbrio da harmonia e desarmonia entre os humores. Essa explicação respalda então uma justificativa plausível para o trabalho excepcional de Gustavo no campo profissional, em que foi reconhecido por sua competência e visão vanguardista da educação. Nesse caso, a harmonia entre os humores do narrador o auxiliou a sobreviver aos seus traumas. $\mathrm{O}$ trabalho, seu antídoto para a melancolia, ajudou-o a rejeitar a complacência para com a tristeza e, no presente da narrativa, por meio de um trabalho de rememoração, pode ressignificar seu passado, como se nota nesta reflexão:

Tudo ajuntado assim, lembranças e não lembranças, começo a pensar que estive errado. Talvez jamais alguém tenha me considerado um traidor, a não ser eu mesmo. E outra coisa, não lembro disso ter sido importante nos últimos vinte anos, mas voltou agora que me aposento, que penso nessa entrevista, que mexo nos papeis velhos para desocupar a casa. De qualquer forma, se guarda tamanha força, não pode ser um falso problema. (BRACHER, 2004, p. 144).

O intervalo que Gustavo teve entre a aposentadoria em São Paulo e a preparação para sua mudança foi repleto de questionamentos sobre a vida útil dos velhos, sobre a relevância de seu trabalho, também de dúvidas sobre a concessão da entre-

7 Ricoeur encontra "nas tradições médica, psicológica, moral, literária e espiritual", antídotos para a melancolia, tais como: "a alegria, o humor, a esperança, a confiança e também... o trabalho." Cf. RICOEUR, 2007, p. 90. 
vista e de lembranças suscitadas pelos objetos e pelo livro do irmão. Desse retorno ao passado proporcionado pela memória que resulta em sua ressignificação, importa saber do que Gustavo se lembra.

Algumas ferramentas de que dispomos para responder à questão “de que há lembrança?" são as definições de lembrança pura e lembrança imagem de Bergson (1963). O filósofo distingue as duas, sendo a lembrança pura aquela que ainda não está posta em imagens. Paul Ricoeur problematiza essa questão e convoca as ideias de Jean Paul Sartre para diferenciar o que é imaginado do que é fictício. Esclarecendo os dois termos pode-se compreender que, enquanto a ficção cria algo que não existe, a imaginação é fundamental para se formar as imagens das lembranças de algo que já existiu. A lembrança imagem trata-se, portanto, da recordação de um acontecimento passado sob a forma de imagens que são formadas na mente para apresentarem um dado-presente no passado (RICOEUR, 2007, p. 69), ela distingue-se substancialmente do que Bergson chamou de lembrança pura.

$\mathrm{Na}$ busca de uma terminologia mais propícia à sua linha de raciocínio, Ricoeur nomeou os dois tipos de lembrança de forma correspondente de lembrança certa e lembrança do tempo passado, respectivamente. Tal nomenclatura coincide com o termo utilizado por Gustavo para denominar uma lembrança que lhe surgiu de forma única, como um arrebatamento, uma lembrança certa. Retomarei essa questão mais adiante.

Obviamente que as lembranças do personagem que nós leitores conhecemos nos são dadas por sua narrativa, portanto, lidamos apenas com suas lembranças imagens. Dessas, algumas foram buscadas por Gustavo, num exercício de recordação, em reflexões apoiadas na anamnese ${ }^{8}$, recorrendo a uma parte de sua memória que está sob mais fácil acesso. Outras afloraram involuntariamente, por meio de objetos, cheiros, sons ou mesmo por recordações de outros. Neste caso faz-se indispensável atuar no plano do imaginário para acessar a memória mais profunda e, no momento presente, reapresentar esse passado por meio de imagens, as quais o personagem nos descreve.

8 Do grego ana, trazer de novo e mnesis, memória. Na concepção platônica anamnesis é uma busca por algo do passado na memória, em oposição a mneme que é uma evocação, o surgimento atual de uma lembrança. À ideia correspondente de anamnesis Sócrates nomeou recordação. 
Partindo desse entendimento, quase toda a construção narrativa de Gustavo advém de lembranças imagens, das que ele busca e das que the afloram. No esforço desse exercício, recorda-se, mesmo que desordenadamente. Ele busca em sua memória e reflete sobre ela com a finalidade de traçar sua biografia, de desenhar para si os caminhos que percorreu, a visão acerca de seus próximos e suas relações de afeição com cada um, bem como suas opiniões sobre a educação e a política.

Alguns objetos, sensações, falas e situações que experiencia suscitam nele um retorno ao passado, são lembranças que acessam a memória mais profunda, utiliza, portanto, a imaginação para abstrair-se do tempo presente e evocar o passado sob a forma de imagens, como explica Bergson sobre a capacidade distinta que o homem tem de sonhar, "de atribuir valor ao inútil” (BERGSON, 1963 apud RICOEUR, 2007, p. 67).

A venda da casa antiga da família, o seu próprio vazio, obriga Gustavo a revirar papéis e objetos dos familiares que lá estiveram ao longo dos anos: "Moldes de dona Joana, anotações escolares da Vóana, rascunhos de atas e manifestos de seu Joaquim, cartas de Jussara, anotações e esboços de Lígia e o livro de José" objetos portadores de lembranças lhe evocam situações das pessoas com as quais conviveu. Segundo o próprio narrador são "Pedaços de vida sem ordem à espera da imaginação"10 . Sendo assim, suas lembranças surgem a partir de suposições do uso daqueles objetos, ou mesmo de presunções sobre quem os manuseou, ou em nítidas imagens quando o objeto fora partilhado também por ele em algum momento. Um exemplo claro dessas recordações a partir de objetos ocorre quando Gustavo encontra um manuscrito do pai, um papel barato com poucas palavras em itens ordenados e, ao lado, um cartaz impresso pelo sindicato, contendo os mesmos itens recheados de muitas palavras mais, inchados de patriotismo, artifício discursivo que irritava seu Joaquim. Ao ver esses papeis, se lembra de como o pai conduzia diplomaticamente os assuntos sindicais e de sua laboriosa e sucinta escolha das palavras.

Num momento de leitura do romance de José, Gustavo constata a inexistência da irmã naquela obra. A partir dessa comprovação começa a buscar em sua memória 
momentos de sua infância com a presença de Jussara e temos, então, uma das mais belas cenas que Gustavo nos relata imageticamente: sua mãe amamentando a pequena ao pé de sua cama,

[...] uma sequência sonora e táctil que se misturava com meus sonhos, choro miúdo crescendo, chinelo de feltro no chão de taco, o peso das duas nos pés de minha cama, suga-suga, entreabria os olhos e via mãe e nenê, uma bola só [...] (BRACHER, 2004, p. 68).

Com este relato podemos perceber que a imagem configura-se para a memória como a presença do ausente, podendo ser compreendida como um vestígio do que está gravado na alma.

Alguns desses vestígios permanecem guardados na mente de uma forma única. Não temos consciência deles, portanto, não são lembranças que podem ser acessadas por uma busca na memória, ou por um objeto que nos leve a recordar tal passagem ou sequer pelo relato de algum próximo. Simplesmente não temos conhecimento da existência de tal vestígio até sermos inconscientemente arrebatados por uma sensação que nos transporta ao passado, seguida da imagem daquele exato instante que provoca o desabrochar do reconhecimento, numa sensação semelhante ao déjà vu. Um célebre exemplo que ilustra esse tipo de arrebatamento é o caso das madeleines (PROUST, 2006, p. 73). A sensação que provocou a junção do gosto e do cheiro das madeleines molhadas no chá involuntariamente colocou Proust em algum lugar do passado que ele não soube reconhecer, pois nenhuma imagem lhe surgiu de imediato. Somente a sensação tomou conta de si e, posteriormente, a cena do passado the surgiu e ele pode reconhecer-se naquela lembrança.

$\mathrm{Na}$ tentativa de compreender esse arrebatamento, interessa-me problematizar sobre a obrigatoriedade ou não da existência de uma imagem quando se presentifica uma lembrança. Talvez, como no exemplo de Proust, para acessar uma lembrança não seja sempre necessário presentificar o passado sob a forma de imagens. Esse questionamento encontra respaldo na possibilidade deixada por Bergson (1963 apud RICOEUR, 2007, p. 68) ao utilizar o termo provavelmente em sua afirmação: "Uma lembrança, à medida que se atualiza, provavelmente tende a viver numa imagem;". 
Recorro também a Santo Agostinho em suas Confissões ${ }^{11}$; quando se refere aos vastos palácios da memória trata das lembranças enquanto percepções e impressões de variadas apresentações, não apenas sob imagens, a explicação sobre a maneira como entraram em sua memória o próprio pensador ignora.

Nas últimas páginas de Não falei, após todo o percurso de elaboração de sua trajetória trabalhando com suas lembranças, Gustavo é dominado por um arrebatamento:

Tenho ainda uma lembrança certa de setenta. Não sabia que tinha, mas ela está aqui, intacta. Dá aflição até, de tão viva, e não existia alguns dias atrás. Mas chega com som, imagem e temperatura, parece que só agora compreendo, quer dizer, vivo esse momento passado. Foi gravado e guardado antes que me desse conta de sua existência. (BRACHER, 2004, p. 146).

Esse ímpeto que toma conta de um ser involuntariamente é a maneira que tem de acessar um vestígio que foi guardado em sua mente de forma única. Gustavo o nomeou de lembrança certa e acredito que podemos associá-lo ao conceito de lembrança pura de Bergson. Compreendo por lembrança pura aquela que surge como um arroubo no plano do sentimento e das sensações que ela provoca em quem se lembra. Ela ocorre no exato momento em que a pessoa é governada pelas sensações e se lembra de algo significativo pela primeira vez, algo até então obscuro para sua consciência. Quando essa lembrança sai do plano das sensações e passa ao plano do imaginário sendo elaborada pela mente, já se configura uma lembrança imagem e pode ser transposta para a oralidade e para a narrativa. A possibilidade que Gustavo tem de descrever esse momento já o torna uma lembrança imagem, pois está raciocinado e construído: apresenta os fatos, os sentimentos e as sensações traduzidos em imagens.

O trabalho de reflexão de Gustavo sobre sua vida, transformando-a numa narrativa para si e, consequentemente, para nós, presentificando o passado de diversas

11 O livro décimo das Confissões (AGOSTINHO, 2002) aborda reflexões e questionamentos sobre a memória. No capítulo $X$ encontra-se: "Mas as realidades significadas por tais palavras, eu jamais atingi com nenhum sentido do corpo, nem as vi em nenhuma parte fora de meu espírito; o que gravei na minha memória não são suas imagens, mas as próprias realidades. Que me digam, se o puderem, por onde entraram em mim! [...] Ignoro." No capítulo XI: "Por isso descobrimos que adquirir tais noções - cujas imagens não atingimos por meio dos sentidos mas que percebemos em nós, sem o auxílio de imagens, tais como são em si mesmas.". 
formas, tem um propósito final — após a ressignificação do passado — , a reconciliação consigo mesmo, o reconhecimento como coloca Ricoeur. O percurso do personagem tem seu ápice no que aquele arroubo de sensações lhe proporcionou, o reconhecimento de si numa lembrança até então bloqueada, no resgate de uma memória impedida ${ }^{12}$. Governado pelas sensações, a lembrança lhe surge impactante, nítida, e Gustavo sente como se estivesse novamente no momento em que conversou com seu pai, em sua casa, após sair da prisão.

A descrição dessa conversa é construída com minúcias e imbricada de um lirismo sutil, captado pela construção plástica da cena e pelos indícios que os detalhes nos fornecem. O fato de Gustavo estar de frente para a janela, olhando para o exterior escuro, sem luz, contrapondo-se ao pai que caminha até ela, olha para o escuro, mas vira-lhe as costas, fornece-nos indícios do estado de espírito em que se encontrava nesse momento, dias após ser solto, ainda desfigurado pelos ferimentos da tortura e sofrendo pela morte da mulher e do amigo. Em meio ao caminhar do pai, narra que olhou para seus chinelos e pensou "[...] há quanto tempo conheço esses chinelos. Eram muito grandes para mim" (BRACHER, 2004, p. 146). Aos leitores, é impossível não compreender que ali, naquele momento, ele sentia-se como uma criança, vulnerável e indefeso, pois já era adulto e os chinelos do pai não podiam ser, de fato, muito grandes para ele. Por diversas vezes naquela cena relata que estava com frio, cansado, impaciente e que queria encerrar a conversa, sendo que, ao longo de sua vida sempre escutou atentamente a voz sensata do pai, que pouco falava. Seu Joaquim, sabendo o valor que suas palavras têm para o filho e intuindo o que ele intimamente desejava àquela altura, lhe diz: "Gustavo, eu estou te falando, sou eu que estou te falando, é importante você saber que não devia morrer [...]" (BRACHER, 2004, p. 147). Fortes indícios de que, provavelmente, Gustavo preferia estar morto a ter que viver e suportar a dor das perdas. Era, afinal, um sobrevivente ${ }^{13}$.

12 Cf. O esquecimento e a memória impedida em RICOEUR, 2007, p. 452.

13 Remeto-me à citação de $A$ trégua, de Primo Levi (2010 apud BRACHER, 2004, p. 121). No trecho, Primo Levi reflete sobre a vergonha de ter sobrevivido ao Holocausto. Esse tema será explorado no próximo capítulo. 
A trajetória de Gustavo ao convocar suas lembranças e reconstituir seu passado ressignificando-o, resulta numa memória feliz, quando a imagem poética completa o trabalho de luto. Há uma metáfora colocada pelo personagem que exprime bem, imageticamente, o que é esse trabalho de busca pela memória feliz:

[...] em meio a um raciocínio complexo [...] somos surpreendidos pelo canto de um passarinho. Talvez já cantasse há tempo [...] mas o percebemos de supetão, nascido junto com nossa alegria inesperada ao ouvi-lo. [...] Destrói sem deixar rastros o fio que laboriosamente construíamos [...]. E, não raro, quando nos damos conta da alegria e do fio perdido e suspiramos resignados em recomeçar o trabalho, a solução aparece tão límpida e inesperada quanto o canto. (BRACHER, 2004, p. 16).

O termo memória feliz não diz respeito à lembrança de algo bom, prazeroso; trata-se de uma memória que é alcançada após um trabalho de busca e que culmina no reconhecimento. É aqui utilizado na concepção empregada por Paul Ricoeur e que exprime o resultado final de um árduo trabalho de recordação, que consiste na realização de um exame das lembranças, culminando num reconhecimento de si que é libertador para o indivíduo. Por sua vez, o propósito do reconhecimento só é alcançado após o trabalho de - utilizando a metáfora aristotélica de "pôr debaixo dos olhos" - trazer algo à tona das trevas para a luz, quando se consegue alcançar o sentimento primigênio da lembrança pura, aquela que, ao surgir inesperadamente e reapresentar o momento passado com a intensidade do momento vivido, preenche de novos significados esse passado.

No caso de Gustavo, a memória feliz se concretiza quando ele se reconhece nas palavras do pai, que o absolve. Sendo assim, todo o trabalho de recordação de Gustavo e suas construções em imagens de lembranças que lhe foram caras, resultaram, ao final da narrativa, no surgimento de uma lembrança pura, uma lembrança que ele nomeia certa e que lhe surge inesperadamente. Naquele momento em que recém saíra da prisão ele estava tão tomado pela dor que não conseguiu considerar as palavras do pai, suprimiu esta lembrança, que ficou até então obscura e inacessível, mas que coroa sua reflexão sobre seu passado e lhe permite sentir-se livre novamente. 


\section{A narrativa do sobrevivente}

Qual há de ser o primeiro, qual o último que hei de contar-te dos sofrimentos, se tantos os deuses celestes me deram?

- Homero, Odisseia, canto IX.

Durante sua jornada de retorno, na grande epopeia ocidental, Odisseu narrou seus feitos e seus trabalhos ao rei Alcínoo e a todos os feácios, longamente e com muitos detalhes. O herói sentiu-se confortável pela calorosa acolhida e pelo ardente interesse daquelas pessoas em ouvir suas histórias, com detida atenção e por tão longo tempo. Ao finalmente regressar para sua amada Ítaca, realizada sua vingança contra os pretendentes e retomado seu leito ao lado da esposa, Odisseu e Penélope contam um para o outro suas dores, cada um precisa falar para o outro o que passou nos vinte anos que estiveram separados.

Desde nossos registros literários mais antigos fica evidente a necessidade vital dos seres humanos de falar sobre si mesmos, de contar um ao outro seus feitos, de serem ouvidos. Ocorre que, sob circunstâncias traumáticas, a necessidade de falar pode ser suprimida pela vontade de calar. Em seu célebre ensaio O narrador, Benjamin (1983) analisa o declínio da experiência e da arte de narrar a partir da constatação de que os soldados voltaram silenciosos da Primeira Guerra Mundial. Posteriormente, Adorno (1992) escreve em Minima moralia que, após a Segunda Guerra, não apenas os soldados voltaram silenciosos do front, mas também as vítimas das perseguições e os que fecharam os olhos às atrocidades do nazismo não tinham nenhuma experiência para narrar. Segundo o filósofo, esse terrível acontecimento teria sido responsável pela destruição da memória coletiva, restando-nos apenas seu conceito.

Fato é que, transposta a barreira da vergonha de ter sobrevivido enquanto tantos pereceram, a literatura mundial conta com um considerável repertório de textos com a temática da perseguição aos judeus. Alguns sobreviventes encontraram meios de narrar o inenarrável e até de contrariar Adorno, que afirmava não ser possível fazer poesia após o Holocausto (ADORNO, 1962). Há consequências irreversíveis do 
impacto que causou mundialmente esse acontecimento. Uma delas é a inauguração das narrativas com forte teor testemunhal, já desde os escritos pós-Primeira Guerra e fortemente mais numerosos pós-Segunda. Como afirma Seligmann-Silva (TIBURI, 2011) sobre a contemporaneidade, "vivemos em uma era de testemunhos" e todas as guerras posteriores à Segunda, tanto quanto os regimes totalitários e ditaduras por todo o globo, corroboraram para a enorme quantidade desse tipo de relato. Para o historiador, todas essas atrocidades geraram silêncios e traumas, mas isso também faz parte do testemunho e relatá-lo é uma forma de denúncia, mas também um processamento do trauma, sendo a escrita, portanto, uma forma de se processar a violência.

O papel da literatura nesse cenário é fundamental para a manutenção da busca pelo sentido da vida após tamanhos horrores. Longe de se tornar uma ferramenta engajada em alguma bandeira ou de servir a representar a sociedade nos seus detalhes, a literatura debruça-se sobre a subjetividade, sem se resumir à psicologia dos personagens nem abdicar do mundo objetivo. O papel dessa arte fica bem demonstrado no fragmento:

\footnotetext{
Não se trata, portanto, de abdicar do sentido da vida, da morte e das dores do mundo. Em sociedades em que a vida humana parece ter perdido todo o sentido, a obra literária é uma procura pelo sentido, estando aí o que Lukács chamou de "missão desfetichizadora da arte". (LUKÁCS, 1966 apud BASTOS, 2012, p. 89).
}

Em Não falei, Gustavo, que já possuía uma história familiar de silêncios, depois de ser submetido a terríveis torturas, perder entes queridos e sofrer a vergonha de ter sobrevivido, cala-se e se fecha. No entanto, contar é tão visceral que ele o faz, mesmo que para si próprio. No farfalhar de seus pensamentos, elabora o que diria à Cecília. Temos então acesso à sua narrativa, àquilo que ele contaria, caso tivesse concedido a entrevista. Essa narrativa, mesmo sendo elaborada apenas em sua mente, atravessada por lembranças certas e quebradas, é a que a autora Beatriz Bracher nos oferece e que venho analisando nesta pesquisa.

Importa observar que Gustavo é um professor experiente, com formação em áreas distintas (biologia, educação e linguística) e, portanto, com uma bagagem signifi- 
cativa de leituras e de vivências. Ao longo do texto essa bagagem aparece nos casos de metalinguagem, nas várias inserções de trechos literários e nas referências a autores. Logo nas primeiras páginas o narrador compara o estilo de escrita do irmão a um plágio de Machado de Assis, e o próprio José a Dom Casmurro, por tentar construir em seus livros um passado que lhe seja dócil ao presente. Há citações de Heráclito de Éfeso, de Edgar Morin, de João Cabral de Melo Neto, de Pedro Nava, de Pedro Nava referindo-se a Casimiro de Abreu, de Primo Levi, de Graciliano Ramos, de João Ubaldo Ribeiro, de Luiz Gonzaga. Há diversas ocorrências de metalinguagens com lemas e músicas tema de resistência à ditadura militar no Brasil, sobretudo com a composição de Geraldo Vandré: Pra não dizer que não falei das flores. Há uma comparação, supostamente humorística, de seu pai com o füher do filme O grande ditador, de Charles Chaplin. Há também referências sutis imbricadas no texto remetendo a passagens de obras de Graciliano Ramos e de Primo Levi.

Nenhuma dessas ocorrências é aleatória, bem como não o são suas digressões sobre etimologia. Gustavo é um amante da linguagem, aproxima a origem das palavras e seus usos ao longo do tempo às palavras que lhe marcaram a trajetória, por exemplo, a busca que faz pelo significado mais antigo da palavra educador, que é arrancar, tirar algo para fora ${ }^{1}$ e a interseção na origem entre os termos traidor e tradutor, na qual ambos significam passar de um lado para o outro ${ }^{2}$. Também de forma perspicaz alinhava momentos de sua vida a passagens literárias e às semelhanças com a vida de seus autores.

Um texto como esse, permeado de referências literárias e artísticas, pode cair nas mãos de um leitor que sequer note ou que não conheça tais menções sem que, no entanto, sua leitura sofra graves prejuízos ao entendimento geral da história. Ou seja, é um romance que, embora recheado de metalinguagens e diálogos com outras obras, não exige pré-requisitos para ser compreendido, não é dirigido a um público específico. Entretanto, quanto maior conhecimento o leitor tem dessas referências maior o romance se torna e infinitas possibilidades de reflexões afloram dessas alusões. 
No primeiro capítulo deste trabalho analisei algumas estratégias textuais utilizadas em Não falei, naquela ocasião as teorias sobre o efeito estético de Wolfang Iser me ofereceram subsídios para tratar da temática dos vazios, pois é pelo conhecimento extratextual do leitor que ele tem condições de decifrar e preencher de significados as lacunas do romance. No que se refere às metalinguagens também os mesmos pressupostos auxiliam a compreensão, pois afirmam que, numa obra ficcional, as alusões literárias indicam a direção que a formação do sistema de equivalências deve seguir (GUMBRECHT, 2002). Sendo assim, o leitor que tem conhecimento dessas referências tende a formar para si um conjunto de correlações entre a presente obra e a que foi referida, remetendo-se aos sistemas de sentido desta para auxiliá-lo a compreender melhor aquela.

Se cada texto literário é um "modelo" de realidade, naturalmente quando ele invoca outra obra para lhe complementar a compreensão está relacionando seu sistema de sentido ao da obra referida. Adoto esses preceitos de Iser (1979) e, como ele, acredito que cada romance extrai os elementos de seu repertório das mais diversas partes do saber social, reproduzindo esse saber e, ao mesmo tempo, estimulando o leitor a buscar apreender o que vai além dele. Numa convergência da estética da recepção, também os desígnios de Mikhail Bakhtin acentuam a riqueza da convocação de várias obras numa mesma, proporcionando a manifestação das vozes sociais, sua teoria da polifonia.

Baseando-me nos estudos sobre as várias vozes de um romance e na estética da recepção, escolhi três referências literárias que aparecem em Não falei para demonstrar que as escolhas metalinguísticas de Bracher não foram aleatórias. São elas as referências a João Cabral de Melo Neto, a Primo Levi e a Graciliano Ramos. A relação entre o romance e as obras vai muito além das citações, implica consideravelmente a história de vida de seus autores, como veremos.

Um trecho da poesia Tecendo a manhã é lembrado após uma reflexão do narrador sobre o que é a memória. Gustavo afirma que, num determinado ponto do real, uma questão surge e sua voz é uma intervenção no que conhece, não consegue definir 
memória, entende que há a posteridade das ideias ${ }^{3}$ e que elas são um desenvolvimento do que veio antes e um argumento ao que virá depois. Em seguida, o trecho da poesia:

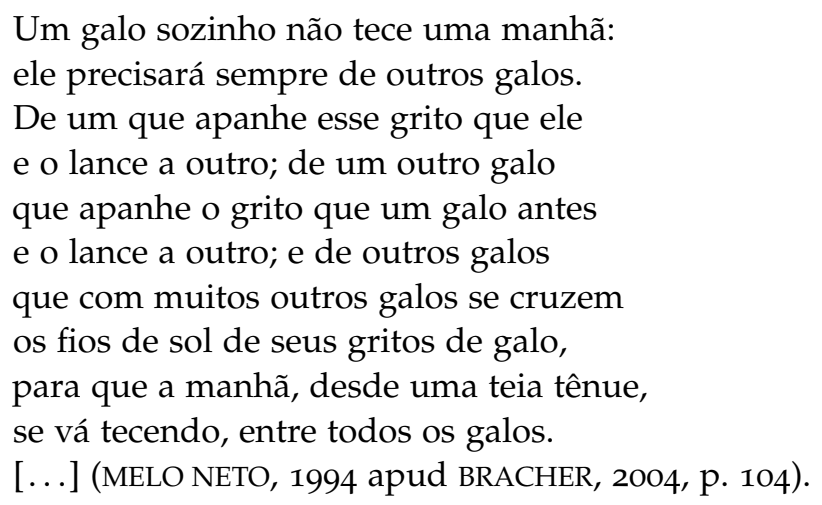

O protagonismo do canto e o próprio canto tornam-se os objetos da análise do narrador, num jogo que alterna o sim e o não. Ele pondera sobre a força e o eco que tem a teia de vários cantos de galo, numa visão de sim, de concordância com a poesia; mas também ressalta a importância do canto solitário de um galo que, mesmo após findo, teve sua luz e sua importância, numa visão de não, discordando da poesia. Neste papel de antagonista Gustavo reflete ainda sobre a posteridade do canto, sobre o uso que é feito dele e das teias: “e um dia, já é hoje, você cantará e no seu canto todos os engolidos soarão." (BRACHER, 2004, p. 105). O que ele disser terá sua importância individual e também como ponto numa coletividade, no entanto, o que lhe incomoda é não saber contra quem estará falando, ou seja, não saber por quem e de que forma sua fala será usada.

Neste sentido, sua reflexão vai ao encontro dos pressupostos de Bakhtin e Iser, mencionados anteriormente, pois Gustavo considera que as ideias de alguém não são inéditas, são o resultado do que essa pessoa pensa a partir da cultura que tem e que, por sua vez, fora adquirida pela sabedoria de várias outras ao longo do tempo. $\mathrm{O}$ conhecimento extratextual do leitor amplia não apenas a compreensão desse romance e das obras a que ele se refere, mas também a percepção de seu contexto histórico, bem como suas correlações com a conjuntura dos textos a que se remete. Sendo assim, a literatura é uma ferramenta inesgotável para o conhecimento de mundo de

3 Para Gustavo o presente é feito por alguém que tece agora a partir do que conhece do que foi tecido por outras pessoas no passado, explicando assim o que ele chama de posteridade das ideias. 
um indivíduo, bem como para a reflexão das questões que permeiam a existência humana.

Sabemos que os discursos podem ser descontextualizados e utilizados conforme o interesse e a oportunidade do momento, talvez essa seja a ressalva do narrador em contar sua história e demonstrar sua visão. Parece sugerir que todas as situações possuem, ao menos, dois pontos de vista e que nenhuma das partes pode ser a detentora da verdade absoluta. No caso desse romance, estamos tratando de vários temas, educação, relações pessoais, memória, velhice, identidade e também de posturas políticas num crucial momento histórico, a ditadura militar no Brasil.

Gustavo deixa claro que discorda totalmente dos militares, de seus métodos e de suas políticas; há trechos em que sutilmente os ridiculariza ao apontar vulnerabilidades de seus integrantes e de seu sistema, como no episódio no qual os policiais foram à sua escola verificar a disciplina de democracia grega e ele solicitou ao professor que reproduzisse a aula para aqueles senhores, eles logo se aborreceram e partiram zangados ${ }^{4}$. Noutros trechos deixa explícita a crueldade de alguns membros militares ao justificarem nas fardas seu gozo com o sofrimento, dor e humilhação de outro ser humano, como em "Os torturadores tinham prazer em bater, mas não batiam por prazer, e sim para coletar informações" 5 .

Porém, apesar de aliar-se a um movimento de resistência, também tece inúmeras críticas a estes, sobretudo aos grupos armados, à fragilidade de suas organizações, à devoção cega a uma ideologia pouco pragmática e à imolação de tantas vidas em prol de uma luta já sangrenta o suficiente: “No final eles [os militares] sabiam mais sobre as organizações do que elas próprias" ${ }^{\prime 6}$. Gustavo opta pela resistência, mas numa frente que ele acredita render mais frutos. Sua trincheira é a sala de aula e os treinamentos de professores; sua ferramenta é a educação, o conhecimento e o pensamento crítico.

Este é o ponto nevrálgico que o liga à obra e aos autores João Cabral de Melo Neto, Primo Levi e Graciliano Ramos. Os quatro comungavam ideais marxistas e 
tiveram ligações com o comunismo, foram vítimas do sistema opressor contra o qual lutaram e, por fim, dedicaram-se a continuar a resistência por meio do trabalho com a linguagem, instigando o pensamento crítico.

Por um despacho de Getúlio Vargas em 1953, João Cabral fora afastado de suas atividades de cônsul acusado de criar uma célula comunista no Itamaraty. Ele recorreu ao Supremo Tribunal Federal e conseguiu retornar a seu cargo no ano seguinte, após, em sua defesa, alegar que não professara ideologia comunista e que fora vítima de uma intriga política. Embora não manifestasse publicamente sua inclinação política, ele era, sim, adepto ao comunismo, como admite em carta ${ }^{7}$ enviada a Carlos Drummond de Andrade, em 1948. No período em que morou na Espanha, país que lhe era de alta estima, exerceu forte influência sobre seus amigos artistas e intelectuais, dentre os quais Joan Miró, Joan Brossa e Antoni Tàpies, apresentando a eles as obras de Karl Marx, difundindo a ideia de que a arte tinha a missão de modificar à ferro a sociedade $^{8}$. Suas obras possuem um claro teor marxista, que pode ser notado nas temáticas, no rigor estético e na expressão antissentimentalista, concreta, que leva o leitor a entrar no território mais ideológico e mesmo conceitual da poesia 9 . No poema em questão, a palavra "grito" ao invés de "canto" — para o som produzido pelo galo - ganha destaque e uma conotação de protesto, um indício de sua visada política de inconformismo com a realidade social.

Primo Levi, judeu italiano, conseguiu doutorar-se em química mesmo depois da segregação racial de Mussolini. Homem das ciências, acreditava que a razão triunfaria, mas, após o colapso do regime, decidiu combatê-lo mais energicamente e ingressou num grupo de partigiani, nome dado às organizações de resistência cujos integrantes tinham grande representatividade comunista. Inexperiente, logo fora preso por milícias fascistas e, ao declarar-se italiano de raça judaica, fora enviado aos nazistas. Em 1944, nas mãos da SS (grupo armado de elite de Hitler), seiscentos e cinquenta

7 Trata-se de uma correspondência pessoal enviada por João Cabral a Drummond em que afirma: "Gostaria de lhe falar de um poema que estou arquitetando e que seria uma espécie de explicação de minha adesão ao comunismo. Como essa palavra é explosiva, chamarei a coisa, [...]" (SÜSSEKIND, 2001).

8 FERNÁNDEZ-MEDINA, 2005, p. 101

9 Ibid., p. 103 
judeus, dentre eles Levi, foram colocados num vagão de um dos famosos comboios alemães para Auschwitz. Desse comboio rumo à morte, apenas ele e outras duas pessoas sobreviveram. Após onze meses de trabalho no campo de concentração, tendo escapado a inúmeras seleções e tido a funesta sorte de ser acometido por escarlatina somente ao final desse período, fora deixado para morrer junto com outros oitocentos judeus quando os alemães bateram em retirada, em janeiro de 1945. Do dia em que os soviéticos chegaram a Auschwitz até o retorno à sua terra natal, Turim, dez meses de longa e dolorosa jornada se passaram. Tendo retomado sua vida, Primo Levi sente a necessidade de contar aos outros o que passara para dar ciência do horror que foi a Segunda Guerra e o nazismo, a fim de que a história do Holocausto jamais seja esquecida $^{10}$. Escreve várias obras ${ }^{11}$ com esse teor testemunhal, seguindo a ordem de suas lembranças e primando por uma linguagem clara, sem enfeites nem apelos, objetiva e crua.

Graciliano Ramos fora vítima do período ditatorial de Vargas, preso em 1936 sob a acusação de difundir ideais comunistas. No entanto, foi justamente nos dez meses que esteve preso que o autor pode conhecer melhor essa ideologia política e alguns de seus membros. Filiou-se ao PCB (Partido Comunista do Brasil) em 1945 e, a partir de então, emprestou seu prestígio cultural para a promoção do comunismo (MORAES, 2012). Não concordava com algumas normas partidárias e algumas vezes entrou em conflito com a direção do PCB, pois esperavam dele um vigor revolucionário pela causa que nunca imputou às suas obras. Não via sentido na literatura panfletária pautada pelo realismo socialista vigente no partido, para ele a literatura é revolucionária por essência e sempre lhe interessava "a literatura como forma superior de testemunho sobre o homem e a história" (BASTOS, 1998, p.25). Encarava o ofício como o fazem

10 Esse dever de memória está submetido à problemática do esquecimento. Os usos e abusos da memória (sobretudo a memória impedida, a memória manipulada e a memória obrigada) relacionam-se de forma complicada com a história, com a memória coletiva e com o perdão. O dever de não esquecer é, ao mesmo tempo, salutar e maléfico para as vítimas. Salutar no sentido de se preservar a lembrança dos que pereceram e do acontecimento, para que não se repita. Maléfico, dentre outros aspectos, pela possibilidade de impedir a realização do luto. Paul Ricoeur detém-se longamente nas questões que envolvem o dever de memória (RICOEUR, 2007).

11 Em 1947 Primo Levi escreve É isto um homem? (LEVI, 1988); publica A trégua em 1963 (LEVI, 2010) e Os afogados e os sobreviventes em 1986 (LEVI, 1990). 
as lavadeiras de Alagoas, lavando, surrando, enxugando e torcendo as palavras até sobrar apenas o essencial.

Os companheiros do partido lhe pediam que escrevesse um livro denunciando o regime opressor, mas Memórias do cárcere só foi escrito dez anos após ficar livre e publicado postumamente. O lançamento, inclusive, causou desconforto entre alguns correligionários, pois Graciliano apresentou com benevolência tanto as pessoas que com ele estiveram presas, quanto os inimigos e alguns dos militares que o prenderam e vigiaram. Essa sua visada multilateral rejeita o pensamento maniqueísta dos dirigentes do partido àquela época e os irrita profundamente. Em Não falei o narrador defende que Infância é a obra que Graciliano escreveu em resposta ao pedido dos correligionários, pois, a seu ver, é a que melhor retrata a opressão, expondo várias de suas facetas, sobretudo a da hierarquia familiar e a do arcaico sistema de ensino ao qual os personagens foram submetidos.

Na referida obra, Graciliano narra as lembranças de uma infância marcada pela repressão, pelo medo e por muitas surras, contém detalhes dolorosos dos efeitos físicos dessas violências e dos instrumentos utilizados para executá-las. No entanto, Gustavo analisa que as surras e suas cicatrizes não são o assunto de Infância, mas sim o medo:

Apanhava, mas esse não é o assunto do livro. Apanhar não é assunto de livro nenhum. Mas o medo de apanhar, esse é grande, medo de errar, medo de não dar conta, de fazer errado de novo, medo de ter medo. E medo não é assunto, é tão grande que não. Não sabe falar. Mas talvez, voltando ao apanhar, talvez o menino se habitue. Faz as contas, vê se a traquinagem vale o preço de um cascudo, vai e faz e depois paga. O terrível, talvez, seja o arbitrário, o inesperado. (BRACHER, 2004, p. 119).

A repressão de si próprio causada pela imprevisibilidade das ações e reações de seus pais circunscreveu ao medo os primeiros anos do moleque José de Infância. Em diversas passagens podemos observar a descrição do pavor do pequeno, não tanto pela dor física que sentiria, mas pelo medo que um conjunto de elementos dessas situações de surra lhe imputavam. No capítulo Um cinturão, o narrador conta sobre suas primeiras relações com a justiça: 
Onde estava o cinturão? Impossível responder. Ainda que tivesse escondido o infame objeto, emudeceria, tão apavorado me achava. Situações deste gênero constituíam as maiores torturas da minha infância, e as consequências delas me acompanharam. [...] Certamente o meu choro, os saltos, as tentativas para rodopiar na sala como carrapeta, eram menos um sinal de dor que a explosão do medo reprimido. [...] O suplício durou bastante, mas, por muito prolongado que tenha sido, não igualava a mortificação da fase preparatória: o olho duro a magnetizar-me, os gestos ameaçadores, a voz rouca a mastigar uma interrogação incompreensível. [...] Foi este o primeiro contato que tive com a justiça. (RAMOS, 2006, p. 35-37).

Detive-me no texto Infância porque percebo similitudes na leitura que os narradores dos dois textos fazem sobre o medo. A reflexão de Gustavo sobre o tema dessa obra vai ao encontro do que reflete sobre sua própria história, sobretudo do período em que esteve preso e foi torturado pelos militares. Nos trechos em que se recorda desses momentos terríveis, deixa claro que os maiores danos que sofreu não foram os causados pelas dores físicas, mas os que o medo do arbitrário, do imprevisível, lhe impuseram. Enquanto preso, não sabia há quanto tempo estava lá; desconhecia a duração e a que tipo de flagelo, torturas físicas ou psicológicas, seria submetido a cada vez que era tirado de sua cela de prisioneiro. Como não tinha conhecimento dos artifícios das organizações para ser persuasivo nos interrogatórios acreditava que nada poderia dizer sobre o amigo, sob o risco de entregá-lo involuntariamente. Obviamente não esperava que sua prisão desencadeasse a morte de Armando, de Eliana e da sogra. Enfim, a mesma espécie de medo do arbitrário e do inesperado foi o que de nefasto aconteceu na história de Gustavo e também na do menino de Infância.

A citação de Primo Levi é a forma que o personagem criado por Bracher encontra de retratar uma experiência lancinante, a dor de ser um sobrevivente. Em meio a uma reflexão que faz sobre os elementos de uma sessão de tortura, Gustavo expressa que não conseguia ver seus algozes como monstros: "Éramos todos homens, impossível apagar de meus neurônios essa informação. Éramos homens." (BRACHER, 2004, p. 121). Justamente o fato de vê-los como semelhantes desperta em si uma profunda vergonha pela fealdade daqueles atos, daquela situação. A vergonha do sobrevivente não é apenas pelas humilhações a que é submetido, mas também por testemunhar atitudes tão bárbaras e bestiais praticadas por seres humanos. Soma-se a 
essas a miséria de saber que tantos pereceram daquela forma e de sentir que sobreviver àquilo, longe de torná-lo um herói, transforma-o numa amálgama de gente.

"Que amálgama de gente é isso?" (BRACHER, 2004, p. 114). O questionamento de Gustavo é sobre o sentimento de compaixão que o afetava sempre que via alguém sendo humilhado, sentia como se a ofensa fosse imputada a ele também. Essa sua frase evoca outra expressão: É isto um homem?, título de uma das obras de Primo Levi, na qual relata as lembranças de Auschwitz. Os campos de extermínio eram os locais propícios para a desumanização de qualquer pessoa, Levi relata que lhes eram retiradas toda e qualquer forma de lembranças que poderiam carregar consigo. Refere-se à condição humana que um dia tiveram, entes queridos, casa, hábitos, roupas, pertences, cabelos e até seus nomes eram reduzidos a puro sofrimento e carência, levando-os a perderem a si mesmos (LEVI, 1988). Era este o objetivo dos campos, transformá-los em animais. No entanto, Levi, embora imerso naquela tragédia, consegue ver nos guardas alemães não monstros, mas seres mecânicos, cumpridores de ordens:

Uma dúzia de SS estava à parte, com ar indiferente, plantados de pernas abertas, mas logo meteram-se entre nós e, em voz baixa, com rostos impassíveis, começaram a nos interrogar. [...] Teríamos esperado algo mais apocalíptico, mas eles pareciam simples guardas. Isso deixavanos desconcertados, desarmados. [...] Sempre com a pacata segurança de quem apenas cumpre com sua tarefa diária. (LEVI, 1988, p. 21).

Essa forma de enxergar o verdugo como um ser humano burocratizado, mecanizado, foi a grande questão sobre a qual se debruçou Hannah Arendt (ARENDT, 1999) e que denominou de banalização do mal, em sua obra Eichmann em Jerusalém. Ao presenciar o julgamento de Adolf Eichmann, um carrasco nazista, a filósofa, que era judia e fugitiva do nazismo, percebe naquele homem um mero cumpridor de ordens, um ser desprovido de raciocínio próprio e que, portanto, não deveria ser considerado um monstro ${ }^{12}$, mas um produto do Estado com sua capacidade destrutiva aliada à burocratização da vida pública.

12 Recordo-me do caso de François Bizot, relatado por Todorov (2009, p. 16) em La memoria, ¿um remedio contra el mal?. Bizot esteve prisioneiro do Partido Comunista em Camboja, fora capturado pelo próprio Duch, diretor do campo de tortura e execução s-21, sendo um dos poucos a sair com vida daquele local. Anos mais tarde, depois de testemunhar no julgamento de Duch, Bizot relatou que a experiência mais perturbadora por que passou foi a semelhança que sentiu entre ele e seu carrasco. Apesar de reconhecer a responsabilidade daquele homem por mais de 40.000 mortes, o ex-prisioneiro admite que ficou transtornado ao ver em seu carrasco "nada de monstruo, ni de perverso, ni de loco; se parece a los demás hombres, y por lo tanto a él mismo". 
A banalização do mal instituída pelo Estado é verificada não apenas no Holocausto, mas em todas as guerras e regimes totalitários. Essa forma de governo, que tantas vezes foi instaurada no Brasil, fez aqui vítimas nas mãos de meros cumpridores de ordens. As mãos que desferem os golpes não são as mãos do Estado, mas sim as de uma pessoa que não raciocina por si própria, de um funcionário a serviço de uma voz imperativa. Por compreenderem dessa forma, tanto Gustavo quanto Primo Levi e Graciliano Ramos, enxergaram seus algozes como seres humanos praticando atrocidades sob as ordens de um poder e, justamente por isso, compadeceram-se do aviltamento daquelas condições humanas e envergonharam-se pelos atos de seus semelhantes.

O trecho de Levi que Gustavo convoca para explicar a vergonha de padecer e sobreviver a isso não poderia ser mais propício, foi o do momento em que as tropas russas chegaram a Auschwitz para libertar os judeus presos:

Não acenavam, não sorriam; pareciam sufocados, não somente por piedade, mas por uma confusa reserva, que selava as suas bocas e subjugava os seus olhos ante o cenário funesto. Era a mesma vergonha conhecida por nós, a que nos esmagava após as seleções, e todas as vezes que devíamos assistir a um ultraje ou suportá-lo: a vergonha que os alemães não conheceram, aquela que o justo experimenta ante a culpa cometida por outrem, e se aflige que persista, que tenha sido introduzida irrevogavelmente no mundo das coisas que existem, e que a sua boa vontade tenha sido nula ou escassa, e não lhe tenha servido de defesa." (LEVI, 2010 apud BRACHER, 2004, p. 121).

Não é fácil compreender porque muitos sobreviventes manifestam tamanha vergonha por terem escapado da morte em tragédias da natureza das trincheiras de guerra, da incomparável aberração que foi o Holocausto, das perseguições e torturas dos regimes militares na América latina, dentre tantos outros exemplos. Uma forma de nos aproximarmos da compreensão de tal sentimento é a leitura dos relatos escritos pelos sobreviventes ou sobre eles. Por isso a convocação de Levi em Não falei é oportuna e elucidativa, o romance nos chama a conhecer outra obra e agregar seu arcabouço de conhecimentos para alcançar o rastro que uma violência arbitrária encerra em suas vítimas. Inteirar-se da obra de Levi é compreender que os sobreviventes são espécies de uma das duas categorias de homens que existem nessas condições: “a dos 
que se salvam e a dos que se afundam"13, que o autor explora profundamente em seu livro Afogados e sobreviventes. É compreender que "frente à pressão da necessidade e do sofrimento físico, muitos hábitos, muitos instintos sociais são reduzidos ao silêncio"14, por conseguinte, os bons não sobrevivem, então, a quem resta fica a vergonha e a culpabilidade.

A convocação dos três escritores foi coerente com as inquietações do narrador. Inconformismo com a estrutura social vigente, sofrimento com penalidades arbitrárias impostas por um regime opressor, reação a esse regime e suas hierarquias por meio de um trabalho com a linguagem e adoção de um ponto de vista que não despreza os outros pontos são elementos em comum que ligam Gustavo a João Cabral, a Primo Levi e a Graciliano. As palavras de Bakhtin sobre o plurilinguismo no romance preenchem de significado a escolha desses autores: "é o discurso de outrem na linguagem de outrem, que serve para refratar a expressão das intenções do autor"15. Quando Beatriz Bracher opta por inserir trechos de determinados autores e obras específicas, está usando a voz deles e de seus personagens para fazer eco às suas intenções de impressão sobre seu leitor e à voz de seu narrador. A palavra refratar traduz exatamente o que pode ocorrer quando o leitor se deixa envolver por essa manobra. No presente da leitura há uma recepção do discurso de outrem que desvia a direção da obra, no entanto, o destino dessa mudança reverbera as intenções da autora e do discurso do personagem.

A convocação daqueles que sofreram na pele com a intransigência de regimes opressores e usaram suas penas como mote para relatar e lembrar ${ }^{16}$ a arbitrariedade desses regimes arrebata os leitores de Não falei a compreender que, mesmo sendo uma obra ficcional, a história é real, aconteceu com milhares de pessoas, em contextos diferentes, sob a tirania de opressões diversas e ao longo de toda a história da humanidade.

\footnotetext{
LEVI, 1988, p. 128

Ibid., loc. cit.

BAKHTIN, 1990, p. 127

6 Os relatos testemunhais e a influência das lembranças pessoais sobre escritos literários podem ser compreendidos sob a ótica de uma memória obstinada, aquela que tem a finalidade de construir e legar uma história verídica, como afirma Almarza (2003). Sobre a importância desses relatos a autora assevera ainda: "Se os indivíduos calam, a sociedade emudece e a história esquece." (Ibid., p. 132).
} 
Há outro ponto instigante em comum entre Gustavo e os três escritores no que se refere à narrativa, a preocupação em polir as palavras. Para João Cabral, Primo Levi e Graciliano esse trabalho de escolha dos vocábulos e burilamento do texto ocorre apenas na individualidade do exercício da escrita, resultando numa obra lapidada. Em Não falei trata-se de uma estratégia textual que permeia todo o romance e que se apresenta desde o início por meio de análises etimológicas, de estudos dos sinônimos e das aplicações dos termos ao longo do tempo. A princípio o leitor pode relacionar isso à formação de linguista do personagem, vendo aí um vício de profissão. No entanto, se decide deter-se nas digressões do narrador percebe que o exercício serve também para espelhar sua personalidade e delatar nuances de sua história.

“Enfim, esse já era o problema, minha esquisitice com as palavras, parar em cada uma, tomá-las na mão, apalpar, observar os vários lados e só depois, ela já toda deformada, deixá-la entrar"17. Gustavo herdara do pai o gosto e o respeito pela linguagem e, como ele, tem conhecimento da "importância e da responsabilidade que as palavras carregam"18. Para seu Joaquim "tirar palavras, limpar, deixar de dizer era

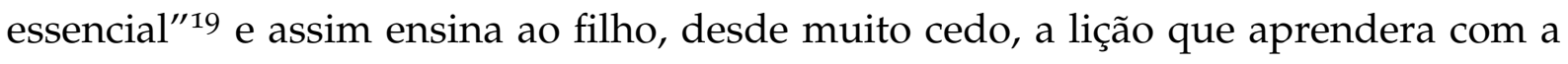
vida, com a sua própria história de lutas:

Texto não é arte, é coisa dos homens e para os homens. As palavras mentem e fazem parte da vida, por isso não podemos nos deixar levar pelo que elas querem roubar da música; a entrega, no texto, é o perigo. Desconfiar sempre que ficar bonito. Claro, queremos convencer, explicar, a beleza ajuda, mas é perniciosa pois cria espaço para a confusão. (BRACHER, 2004, p. 134).

A perspicácia na escolha das palavras é o que promove a sutileza da poesia de João Cabral, que vai além do que suas linhas encerram. A escolha de uma linguagem lúcida, direta e desprovida de apelos dramáticos faz das obras de Primo Levi os melhores relatos sobre o Holocausto. O trabalho de lavadeira de Graciliano Ramos com a linguagem deixa em evidência o relevante, o essencial, sem enfeites nem brilhos. Para esses autores não há entrega ao texto, mas sim sua lapidação; não há acessórios, primam pelo primordial. 
A narrativa de Não falei é constituída pelas lembranças desordenadas de um velho homem que elabora em sua cabeça sua história, numa busca pelo reconhecimento de si. Um romance, portanto, que não apresenta apenas o essencial, posto que é estruturado sobre os pensamentos de Gustavo, mas bastante perspicaz aos termos que descrevem e nomeiam as relações dessa história.

A propósito dos nomes, Gustavo afirma: “Um nome é um modelo mas é também um espelho. É também um lugar no mundo. O que tem nome existe. É preciso e irremediável"20. Diante de tal afirmação é curioso notar que é justamente ele o último a ser nomeado no romance. A primeira referência ao seu nome encontra-se já bem adiantada a trama, num trecho do romance de José: "Os gêmeos Amado e G. e eu"21. No romance do irmão, Gustavo é só uma letra: G. Quase no final da obra, ao ler anotações da irmã, surge algo mais substancial, um apelido no diário de Jussara: "O Guto chegou ontem"22. Gustavo apenas é nomeado nas últimas páginas do romance, e quem o faz é seu Joaquim: "Gustavo, ele diz, Armando colheu a morte que plantou"23.

O fio condutor desse romance é a busca pelo reconhecimento. Ao resgatar suas lembranças e elaborá-las numa narrativa para si, a identidade de Gustavo vai se formando, para ele e para nós leitores. Seu nome se torna conhecido apenas no exato momento em que ele se reconhece nas palavras do pai, que o nomeia e o redime, e ele pode, assim, reassumir seu lugar no mundo.

BRACHER, 2004, p. 62

21 Ibid., p. 56

22 Ibid., p. 136

23 Ibid., p. 146 


\section{Conclusão}

O conhecedor de arte é comparável ao detetive que descobre o autor do crime (do quadro) baseado em indícios imperceptíveis para a maioria. - Carlo Ginzburg, Paradigma indiciário.

A jornada empreendida por Gustavo em suas rememorações configurou-se uma busca pelo reconhecimento de si. Conhecemos essa demanda juntamente com o personagem e, tanto quanto ele, atentamo-nos às pistas que cada elemento da trama nos forneceu: lembranças, acontecimentos, reflexões suas e mesmo aparentes insignificâncias.

Para desenvolver essa pesquisa, como mencionado na introdução, inspirei-me nos estudos fenomenológicos de Paul Ricoeur e também nos de alguns autores que ele convoca, como Henri Bergson, Maurice Halbwachs, Sigmund Freud e Santo Agostinho. Mas, dos convocados por Ricoeur, credito sobretudo a Carlo Guinzburg a grande influência sobre minha abordagem do romance. Foi seu Paradigma indiciário (GINZBURG, 1989) que aguçou minha sensibilidade para uma visada epistemológica na leitura de Não falei, propiciando o alcance das conclusões que a esta altura apresento.

Um dos objetivos deste trabalho era demonstrar como a história revelou-se por meio da peculiaridade narrativa de ausências, vazios e silêncios. Também evidenciar que o calculado deixar para o leitor o juntar de peças das lembranças propiciou a compreensão e, em certa medida até a experimentação, da complexa situação psicológica de Gustavo, decorrente de sua trajetória de percalços e dores lancinantes. Nesse sentido, buscou-se demonstrar que o trabalho com a linguagem conseguiu expressar as reflexões e as sensações vivenciadas pelo protagonista ao lançar mão de sua memória da maneira fragmentada que se apresenta, contando com o preenchimento de sentidos a partir da experiência de cada leitor. Por fim, por objetivo mais abrangente, buscou-se demonstrar que, a partir das reflexões suscitadas pela obra, não apenas o personagem pode ressignificar seu passado, mas também nós leitores, por analogia, devido à semelhança de sua história com a de tantos sobreviventes, pudemos compre- 
ender e recuperar o passado coletivo da realidade educacional e política brasileira no período narrado por Gustavo e as consequências dos ocorridos dele na atualidade.

O fato de conhecermos o nome do protagonista apenas nas últimas páginas do romance, especialmente naquela sua lembrança certa, não chegou a ser um ingrediente de suspense, até porque esse é um dos vazios que pode passar desapercebido ao leitor, mas, sem dúvida, foi um elemento chave para o desfecho da história. No livro de José, Gustavo era apenas uma letra, isso ele bem observara e o incomodara na ocasião, pois, a seu ver, o nome é um modelo, um espelho e um lugar no mundo. Essa sua convicção, colocada a quase meio caminho da obra, forneceu-nos indícios valiosos para alcançarmos a dimensão do que aquela lembrança final lhe proporcionara. Como não deduzirmos que a fala absolta do pai servira não apenas para nomeá-lo, para recolocá-lo em seu lugar no mundo, mas também para completar seu percurso de reconhecimento e conclamá-lo a se perdoar ${ }^{1}$ ?

A identidade de Gustavo se constrói para nós e se reconstrói para ele no desdobrar da narrativa, ele se reconhece na história que contou para si mesmo. O enredo perpassou elementos não apenas fornecidos por sua memória, mas também pelo momento a que estava submetido. Celebrações de despedida por sua aposentadoria, a entrevista que deveria conceder à Cecília, o romance de José, objetos de seus entes queridos, todos esses dados contribuíram significativamente para a construção de sua trajetória e para a compreensão da complexidade desse personagem, como vimos no segundo capítulo.

Nesse sentido, importa observar os elementos que apareceram mais explícitos na trama, como as questões relativas à ditadura militar e às transformações no sistema educacional brasileiro por ela impostas. Também aqueles que foram apresentados de forma velada, como o silêncio familiar e as relações entre o termo traição e Gustavo. Sobretudo, não se tratando de observar, mas sim de apreender, importa considerar o que apareceu no romance de forma intangível, como os vazios e o silêncio primordial que perpassaram toda a obra.

Para Ricoeur (2007, p. 465) o perdão, "se tem algum sentido e se existe, constitui o horizonte comum da memória, da história e do esquecimento. [...] Ele é tão difícil de se dar e de se receber quanto de se conceituar." Pela extensão e complexidade do tema, nesta ocasião não me debrucei sobre o perdão, no entanto, na esteira do filósofo, compreendo esse termo como algo mais profundo que sua utilização habitual encerra. 
Não podemos considerar que a ditadura militar seja o pano de fundo desse romance, longe disso, posto que foi justamente a prisão de Gustavo pelo regime que desencadeou uma série de acontecimentos que mudaram completamente os rumos de sua vida e de muitas pessoas à sua volta. No entanto, esse período histórico também não é o tema central da obra. Pelas análises realizadas, considero que Não falei é um romance sobre a busca de um indivíduo pelo reconhecimento de si após ter sofrido com as sequelas dos traumas que sua prisão desencadeou.

Os relatos do personagem sobre o regime, embora façam parte de uma obra fictícia, encontram verossimilhança respaldada nos testemunhos ${ }^{2}$ de sobreviventes e de parentes dos mortos políticos da última ditadura brasileira. Portanto, cabe perfeitamente afirmar que a narrativa de Gustavo rendeu excelentes reflexões sobre esse contexto histórico e acrescentou à compreensão dos acontecimentos políticos já conhecidos $^{3}$, bem como das ações dos movimentos e organizações de resistência.

No entanto, creio que a grande contribuição de Não falei para esse tema diz respeito ao universo particular do sobrevivente. Conhecer os sentimentos e sensações de Gustavo sobre o regime, desde as razões que motivaram seu alijamento à resistência, o cálculo dos riscos da vida clandestina, as sevícias de sua tortura e suas sequelas físicas e psicológicas, as consequências da prisão arbitrária de um ente querido para os familiares, todos esses elementos nos propiciaram alcançar o legado traumático que involuntariamente herda quem sobrevive a brutalidades dessa natureza.

Outra herança nefasta dessa forma de governo e que também pudemos alcançar pelo romance foi a decadência do sistema de ensino, em que as salas de aula deixaram de ser espaços dialógicos nos quais questionar é salutar e tornaram-se meros locais de reprodução de conceitos, estes selecionados de acordo a não ferir os interesses do regime. O que Cecília chama de "vazio agressivo" na educação incomoda Gustavo

2 Duas obras testemunhais tiveram importância fundamental para a ampliação de minha fortuna crítica sobre a ditadura militar no Brasil. O livro K. do jornalista Bernardo Kucinski (KUCINSKI, 2012), no qual utiliza elementos ficcionais para completar os vazios da história verídica de sua irmã, Ana Rosa Kucinski. Ela foi sequestrada e desaparecida pelos militares junto com seu marido Wilson Silva, em 22 de abril de 1974. A outra obra é Lembranças da luta armada e do exílio, de Evandro Afonso do Nascimento (NASCIMENTO, 2009), uma autobiografia de sua trajetória na resistência à ditadura, desde as origens de seu alijamento ao que vivenciou nos países em que esteve exilado.

3 Cf. Relatórios da Comissão Nacional de Verdade. Disponível em: <http://www.cnv.gov.br/> 
pelo fato de conhecer profundamente suas raízes e por sentir-se também vítima de suas consequências. Ao longo de sua experiência como educador conhecera as demandas e vicissitudes de todos os lados da tríade que compõe a educação: a instituição escolar, o aluno e a família do aluno.

Dos relatórios que fez para o secretário de educação, aos cursos de recapacitação de professores que ministrou e às enfadonhas celebrações de sua aposentadoria, o personagem identificou uma crônica ausência de pensamento crítico por parte dos responsáveis nas instituições. Os alunos foram identificados por ele nesse sistema como os seres cujo conhecimento foi relegado à categoria das desimportâncias e, sem espaço para a inserção no rol das relevâncias educacionais, ficaram restritos à configuração social escolar, donde deduzirmos os papéis típicos de alunos: os exemplares, os medíocres, os problema, e mesmo os palhaços, como no caso de Benício, que foi longamente relatado. Por sua vez, o papel das famílias nesse contexto educacional inexpressivo era o de garantir o bom comportamento dos filhos na escola e o cumprimento das tarefas, sendo assim e considerando o contexto social, em que os pais deviam trabalhar o dia todo para garantir o sustento da família, restava-lhes a violência como ferramenta para fazer valer essa garantia.

Dos elementos que foram apresentados na trama de forma velada, o silêncio familiar surgiu algumas vezes despropositadamente, ou ao menos assim aparentaram até que o leitor percebesse sua importância. Analisei também algumas das relações que foram feitas de forma oculta entre o termo traição e Gustavo. A história do personagem foi marcada por esse vocábulo desde seu nascimento, podendo-se compreender essa afirmação pela reflexão que faz a partir de um trecho do livro de José em que não fica explícito, apenas sugerido, o fato de ele ter sido o irmão gêmeo que sobreviveu:

Uma casa geminada, um gêmeo, são indivíduos, estão inteiros, mas trazem em seu nome o outro. [...] você pensou muitas vezes, olhando essa casa geminada entre dois edifícios, eu fui um gêmeo, mas meu gêmeo nasceu morto. (José foi longe buscar minha sanha, ou sina, ou sinal de Caim) Se demolíssemos uma das casas a outra continuaria sendo geminada, está na sua arquitetura, [...] Não deixo, então, de ser um gêmeo, não uma parte mas um indivíduo que carrega em sua estrutura um outro, inexistente. (BRACHER, 2004, p. 28-29). 
Anteriormente não explorei esse elemento da trama em particular, porém convém convocá-lo neste ponto para obtermos conclusões mais completas sobre as ocorrências de traição e de sobrevivência na vida do personagem, certamente as matérias mais pungentes de sua história.

Evidentemente, Gustavo não fora culpado pela morte do irmão, mas, apesar de ter ciência de que era apenas um bebê, ele carrega consigo essa responsabilidade, verificada pelas palavras que utiliza: sanha, sina, sinal de Caim. A palavra sanha relaciona-se a rancor, sina é o mesmo que destino e Caim faz referência ao personagem bíblico que matou seu próprio irmão, Abel, história narrada no livro de Gênesis.

Mais uma vez, as referências escolhidas mostraram-se nada aleatórias e essas inserções delataram a origem de duas perturbações com as quais Gustavo frequentemente teve de lidar ao longo de sua vida: a culpabilidade que facilmente assimilava e sua vergonha de ser sobrevivente. Parece que seu destino fora traçado sob o signo da traição e da sobrevivência, a começar pelo nascimento. Escolheu por profissão ser educador, termo que também se relaciona com sua sina, já que o significado original desse vocábulo é o de arrancar algo de dentro para fora, como o próprio narrador informa. Posteriormente, quando de sua prisão e tortura, decorridas as tragédias oriundas desse evento, foi implicitamente acusado de trair e entregar o amigo, restando-lhe, portanto, o rancor, a mágoa e a raiva por tudo o que aconteceu; seu ensimesmamento por sua impossibilidade de ação diante de tamanhas atrocidades e, por fim e de forma bastante complexa como vimos no terceiro capítulo, sua vergonha de ser um sobrevivente. Com a filha, Lígia, também se identificou como traidor quando confirmou para ela as revelações da amiga sobre os cemitérios, ele sentiu como se traísse a inocência da menina e as cerimônias dos domingos que ambos tanto apreciavam. Até mesmo sobre enviar à Cecília os relatórios que fez para a secretaria de educação Gustavo vislumbrou traição: “Talvez hesite porque mandar as cartas seja uma forma de trair Otávio." (BRACHER, 2004, p. 56).

Isto posto, é possível compreender melhor o percurso de Gustavo, bem como seus sentimentos em relação aos acontecimentos que lhe marcaram a trajetória. Aten- 
tando-nos aos detalhes quase negligenciados de sua narrativa embaralhada, alcançamos a amplitude do que foi para ele reconhecer-se em sua própria história que, dentre outras benesses, trouxe-lhe o entendimento de que por toda a vida fora "não uma parte, mas um indivíduo que carrega em sua estrutura um outro, inexistente", sendo este último tudo e todos aqueles a quem julgou ter traído. O reconhecimento da diferença entre ele e esse outro é a consciência da alteridade (BRANDÃO, 1986, p. 7), ou seja, depois da narrativa de sua vida que faz para si mesmo, Gustavo consegue distinguir o que fora atribuição sua, de fato, e o que fora responsabilidade de outros ou das circunstâncias.

Realizadas essas distinções, o próximo passo no trajeto do reconhecimento foi sua identificação. Finalmente ele compreendeu que não era aqueles outros que carregara, e a narrativa que fez para si forneceu os elementos de que necessitava para proceder a reconstrução e aceitação de sua identidade. Neste aspecto, faz-se imprescindível apreender de sua história o que aparece de forma intangível e que analisei detidamente no primeiro capítulo, a saber, todas as formas de vazios, sobretudo as ausências.

Como ocorre com todo ser humano, apenas Gustavo fora o protagonista de sua vida e, portanto, o único a experimentar as sensações de cada momento seu, principalmente naqueles de ausências, em que se encontrava extremamente só. Também, ao revisitar suas lembranças e contrastá-las com as do irmão narradas em seu romance, Gustavo pode constatar que a visão deles era bastante diversa sobre a conjuntura familiar que partilharam e que o silêncio que pairava sobre a casa imprimiu sequelas diferentes sobre cada um. José não suportou viver muito tempo com a família, saiu de casa aos dezessete anos, depois precisou escrever para verbalizar o que não fora dito a ele e o que ele não dissera aos seus próximos, tornou-se palavrório, não poupava discursos nem quaisquer temas. Gustavo manteve-se na mesma casa, inclusive conservando-a sem mudanças, aprendeu a ser silencioso, herdou do pai o prazer pela arquitetura das palavras, calou-se, refugiou-se no trabalho e em suas manias e hábitos, muitos deles assimilados dos antigos costumes de Armando e de seu Joaquim. Foi o percorrer das lembranças e a decisão por um novo desafio de vida na velhice que 
lhe conduziram por uma longa reflexão que é o seu próprio romance não escrito, Não falei.

Diferente do livro de José, o livro de Gustavo não foi escrito. Não falei é a consciência de Gustavo, é o que ele pensou, lembrou, sentiu, tudo temporalmente desorganizado, tematicamente desconcatenado. Nada foi dito, pois, para ele, dizer não foi e nem seria possível. Gustavo só contaria alguma história se fosse possível um pensamento sem palavras ou imagens, inteiro sem tempo ou espaço, mas por ele criado, uma revelação do que nele e dele se escondesse e pronto estivesse, se fosse possível que nascesse sem origem aos olhos de todos. Como isso não foi possível, ele não falou. 


\section{Referências}

ADORNO, T. W. La crítica de la cultura y la sociedade. Tradução Manuel Sacristán. Barcelona: Ediciones Ariel, 1962. 183 p.

Minima moralia: reflexões a partir da vida danificada. Tradução de Luiz Eduardo Bicca. São Paulo: Ática, 1992.

AGOSTINHO, S. Confissões. Tradução Alex Marins. São Paulo: Martin Claret, 2002. $432 \mathrm{p}$.

ALMARZA, S. Assim falou saramago! Memória e direitos humanos. Diálogos latinoamericanos, v. 7, p. 130-133, 2003. Disponível em: <http://lacua.au.dk/ publikationer $/ \mathrm{dl}_{7} />$. Acesso em: 17 fev. 2015.

- O reconhecimento à luz do pensamento de Paul Ricoeur. Cerrados: revista do Programa de Pós-Graduação em Literatura, v. 34, p. 219-228, 2012.

ARENDT, H. Eichmann em Jerusalém: um relato sobre a banalidade do mal. Tradução José Rubens Siqueira. São Paulo: Companhia das Letras, 1999. 344 p.

BAKHTIN, M. M. Forms of time and of the chronotope in the novel. In: The dialogic imagination: four essays. Tradução Caryl Emerson e Michael Holquist. Austin: University of Texas Press, 1981. cap. 4, p. 84-258.

Questões de literatura e de estética: a Teoria do Romance. Tradução Aurora Fornoni Bernardini et al. 2. ed. São Paulo: Hucitec, 1990. 440 p.

BASTOS, H. J. de M. Memórias do cárcere, literatura e testemunho. Brasília: Editora Universidade de Brasília, 1998. 169 p.

As artes da ameaça: ensaios sobre a literatura e crise. Outras Expressões: São Paulo, 2012. $152 \mathrm{p}$.

BENJAMIN, W. O narrador. In: CIVITA, V. (Ed.). Textos escolhidos. 2. ed. São Paulo: Abril Cultural, 1983.

BERGSON, H. Matière et mémoire. Essai sur la relation du corps à l'esprit. In:

Oeuvres. 2. ed. Paris: Presses Universitaires de France, 1963.

BORGES, J. L. Funes, o memorioso. In: . Ficções. Tradução Davi Arrigucci Jr.

São Paulo: Companhia das Letras, 2002.

BOSI, E. Memória e sociedade: lembranças de velhos. 3. ed. São Paulo: Companhia das Letras, 1994. $484 \mathrm{p}$.

BRACHER, B. Não Falei. São Paulo: Editora 34, 2004. 152 p.

BRANDÃO, C. R. Identidade e Etnia. São Paulo: Brasiliense, 1986.

FERNÁNDEZ-MEDINA, N. Tradição e ruptura: João Cabral de Melo Neto em Barcelona, 1947-1950. Luso-Brazilian Review, 2005. 
FREUD, S. Trauer und melancholie. In: . Gesammelte Werke. Frankfurt: S.

Fischer, 1946. v. 10.

GINZBURG, C. Mitos, emblemas, sinais. Tradução Federico Carotti. 3. ed. São Paulo: Companhia das Letras, 1989.

GUMBRECHT, H. U. A teoria do efeito estético de Wolfgang Iser. In: LIMA, L. C. (Org.). Teoria da literatura em suas fontes. Rio de Janeiro: Civilização Brasileira, 2002. v. 2, p. 417-441.

HALBWACHS, M. A Memória coletiva. Tradução Laurent Léon Schaffter. São Paulo: Vértice/Revista dos Tribunais, 1990. 189 p.

ISER, W. A interação do texto com o leitor. In: LIMA, L. C. (Org.). A literatura e o leitor: textos de estética da recepção. Rio de Janeiro: Paz e Terra, 1979. p. 83-132.

KOVADLOFF, S. O silêncio primordial. Tradução Eric Nepomuceno e Luís Carlos Cabral. Rio de Janeiro: José Olympio, 2003. 192 p.

KUCINSKI, B. K. 2. ed. São Paulo: Expressão Popular, 2012. 184 p.

LEVI, P. É isto um homem? Tradução de Luigi Del Re. Rio de Janeiro: Rocco, 1988. $256 \mathrm{p}$.

Os afogados e os sobreviventes. Tradução Luiz Sergio Henriques. Rio de Janeiro: Paz e Terra, 1990. $216 \mathrm{p}$.

A trégua. Tradução Marco Lucchesi. São Paulo: Companhia das Letras, 2010.

LUKÁCS, G. Estética: la peculiaridad de lo estético. Problemas de la mímesis. Barcelona: Grijalbo, 1966.

MELO NETO, J. C. de. Obra completa: volume único. Rio de Janeiro: Nova Aguilar, 1994. $836 \mathrm{p}$.

MERLEAU-PONTY, M. Das Auge und der Geist. Philosophische Essays. Tradução Hans Werner Arndt. Hamburg: Reinbek, 1967. Título original: L'oeil et l'esprit.

MORAES, D. de. O velho Graça: uma biografia de Graciliano Ramos. São Paulo: Boitempo Editorial, 2012. 360 p.

NASCIMENTO, E. A. do. Lembranças da luta armada e do exílio: Chile, Panamá, República Democrática Alemã e Costa Rica. Uberlândia: Edição do Autor, 2009. 193 p.

PROUST, M. No caminho de swann. Tradução Mario Quintana. 3. ed. São Paulo: Globo, 2006. 558 p. (Em busca do tempo perdido, v. 1).

RAMOS, G. Infância. 38. ed. Rio de Janeiro: Record, 2006. 316 p.

RICOEUR, P. A memória, a história, o esquecimento. Tradução Alain François et al. Campinas: Editora da Unicamp, 2007. 536 p. 
SÜSSEKIND, F. Correspondência de Cabral com Bandeira e Drummond. Rio de Janeiro: Nova Fronteira, 2001. 319 p.

TIBURI, M. Entrevista - Márcio Orlando Seligmann-Silva. Trama Interdisciplinar, v. 2, n. 1, p. 8-18, 2011. Disponível em: <http://editorarevistas.mackenzie.br/index. $\mathrm{php} /$ tint/article/view/3963>. Acesso em: 18 fev. 2015.

TODOROV, T. La memoria, ¿um remedio contra el mal? Tradução Manuel Arranz. Barcelona: Arcadia, 2009. 39 p. 